\title{
Measurements of volatile organic compounds in the middle of Central East China during Mount Tai Experiment 2006 (MTX2006): observation of regional background and impact of biomass burning
}

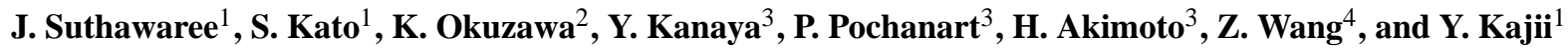 \\ ${ }^{1}$ Department of applied chemistry, Faculty of Urban Environmental Sciences, Tokyo Metropolitan University, \\ 1-1 Minami-Osawa, Hachioji, Tokyo, 192-0397, Japan \\ ${ }^{2}$ Institute of Low Temperature Science, Hokkaido University, N19 W8 Kita, Sapporo, 060-0819, Japan \\ ${ }^{3}$ Frontier Research Center for Global Change, Japan Agency for Marine-Earth Science and Technology, \\ Yokohama, Kanagawa, 236-0001, Japan \\ ${ }^{4}$ LAPC/NZC, Institute of Atmospheric Physics, Chinese Academy of Sciences, Beijing, 10029, China
}

Received: 28 July 2009 - Published in Atmos. Chem. Phys. Discuss.: 7 August 2009

Revised: 17 January 2010 - Accepted: 28 January 2010 - Published: 5 February 2010

\begin{abstract}
The measurement of volatile organic compounds (VOCs) was carried out at the summit of Mount Tai, located in the center of the Central East China (CEC) region, in June 2006 as part of the Mount Tai Experiment 2006 (MTX2006), which focused on the ozone and aerosol chemistry in the region. Temporal variations of simple VOCs between 2 June and 28 June revealed the characteristics of an aged air mass with minimum local influence. A comparison of VOCs observed at Mount Tai with other Chinese sites revealed relatively similar VOC levels to remote sites and, as expected, a lower level compared to more polluted sites. However, relatively high acetylene and benzene levels at Mount Tai were evidently indicated from comparison with normalized VOC profile by ethane suggested for Beijing. Owing to a shift in boundary layer height, we observed considerable differences between daytime and nighttime VOC mixing ratios. This suggests that the site potentially has a very useful characteristic of being able to measure regional polluted air and the free troposphere regional background air quality. Influence of emissions from biomass burning in the region was evidently found to be extensive during the first half of the campaign (2-15 June), using fire spot data coupling with backward trajectory analysis. Agricultural residue burning was suggested as the primary source of emissions elucidated by the slope of the correlation plot between $\mathrm{CH}_{3} \mathrm{Cl}$ and $\mathrm{CO}$ obtained during the first half of the campaign.
\end{abstract}

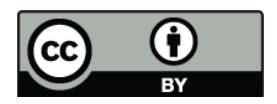

Correspondence to: J. Suthawaree (deutschf@tmu.ac.jp)

\section{Introduction}

Volatile organic compounds (VOCs) are an important ingredient along with the presence of nitrogen oxides $\left(\mathrm{NO}_{\mathrm{x}}=\mathrm{NO}+\mathrm{NO}_{2}\right)$ and sunlight in the photochemical production of surface $\mathrm{O}_{3}$. Therefore, in order to understand the mechanism of tropospheric $\mathrm{O}_{3}$ production, the measurement of VOCs is essential. The developments of countries in the East Asia region, especially China - the world's most populated country with a population of more than 1.3 billion (Central Intelligence Agency - CIA, 2008) - has resulted in an inevitable increase in primary and secondary air pollutants, including $\mathrm{O}_{3}$ (Kato and Akimoto, 1992; Streets and Waldhoff, 2000; Akimoto, 2003; Wang et al., 2005). An Asian emission inventory revealed a decreasing trend of black carbon emissions in China from the present to 2020 due to the transition to more advanced technology (Streets et al., 2001). Nonetheless, the emissions are projected to continually increase for $\mathrm{CO}(190 \%), \mathrm{NO}_{\mathrm{x}}(150 \%)$, nonmethane VOCs (NMVOCs) (50\%), and other species in eastern China (Wang et al., 2005). An increasing trend for $\mathrm{SO}_{2}$ and $\mathrm{NO}_{x}$ in China was also reported by Streets and Waldhoff (2000). An emission inventory of NMVOCs by Klimont et al. (2002) projected an increase of $64 \%$ in 2020 in China - the east and south coasts especially are projected to increase by a factor of more than two - and a shift from stationary emission sources (coal and biofuel) to the typical sources of developed economies (transportation and chemical-related industries and petroleum). Studies of the long-range transport of Asian air pollutants (e.g. Blake et al., 2003; de Gouw et al.,

Published by Copernicus Publications on behalf of the European Geosciences Union. 
2004; Parish et al., 2004, Wong et al., 2007; Suthawaree et al., 2008) has raised the issue of excess anthropogenic emissions in Asia to a global concern.

VOC mixing ratios in China have been reported for various regions, mostly in developed areas (roadside and urban locations). In addition to the observations of the Hong Kong urban environment (Chan et al., 2002; Ho et al., 2002; So and Wang, 2004; Tsai et al., 2006; Guo et al., 2007), measurements of nonmethane hydrocarbons (NHMCs) and halocarbons were extensively carried out in industrial cities on the Pearl River Delta (PRD), which is the most economically dynamic area in the south China region. The results indicated a great contribution of industrial emissions to ambient levels of these compounds in the surrounding provinces (C. Y. Chan et al., 2006; L. Y. Chan et al., 2006, 2007; Tang et al., 2007; Liu et al., 2008a). Barletta et al. (2005) identified the primary sources of VOCs in 43 Chinese cities as combustion-related activities including vehicular emission, coal and biofuel usage, and gasoline evaporation. A more recent report (Barletta et al., 2006) showed an enhancement in ambient mixing ratios in Chinese cities of halocarbons with respect to the global background. Despite a great understanding of China's urban air pollution, information regarding VOC mixing ratios in rural and remote environments in China, where approximately $80 \%$ of population lives, is still limited to a few sites. Correlation plots between trace species and CO at Lin'an, a rural station in eastern China, suggested the impact of mixed biomass/biofuel usage and industrial/urban emissions in the spring season (Wang et al., 2004). However, a strong correlation between $\mathrm{CH}_{3} \mathrm{Cl}$ and $\mathrm{CO}$ observed in autumn at this site revealed the exclusive influence of biomass/biofuel burning (Wang et al., 2002). Consistent with previous studies, Guo et al. (2004) used principal component analysis to identify the major sources of VOCs and $\mathrm{CO}$ at Lin' an as biofuel burning and vehicular emissions. The two sources contribute to more than $70 \%$ of the total VOCs. A similar result was obtained during observations of a rural site in Hong Kong, where 50\% of the total VOCs was attributed to combustion sources (Guo et al., 2007). The effect of anthropogenic VOC emissions was also observed in the rural area of Changchun, one of the biggest cities in northeast China (Liu et al., 2000). At the remote Jianfeng Mountain site (Hainan Island in southern China), the characteristic of aged air masses was elucidated by low ratios of NMHCs to acetylene compared to other rural sites (Tang et al., 2007).

There is limited knowledge on VOCs in the Central East China (CEC) region, despite the recent discovery of high $\mathrm{O}_{3}$ concentrations over the region with a maximum hourly average of $120 \mathrm{ppbv}$ (Pochanart et al., in preparation). In addition, the $\mathrm{O}_{3}$ production in this region, was suggested by model simulation coupled with precursors' mixing ratios derived from emission inventories to be VOC-limited regime (Luo et al., 2000; Carmichael et al., 2003). Similar conclusion was also drawn from measurement during summer in
Beijing area (Shao et al., 2009) where aromatics, alkenes, and isoprene were found to significantly impact the Ozone Formation Potential (Xie et al., 2008). However, validated VOC data from observation is needed together with other precursor data to be facilitated in the model study of the actual scenario. The model eventually yielded a general conclusion of the $\mathrm{NO}_{\mathrm{x}}$-limited regime at Mount Tai (Kanaya et al., 2009). Therefore, information regarding VOC characteristics and behavior is essential to understand regional air pollution.

The Mount Tai Experiment (MTX2006), an intensive measurement campaign, was conducted through collaboration between Chinese and Japanese groups of scientists - Frontier Research Center for Global Change (FRCGC), the Japan Agency for Marine-Earth Science and Technology (JAMSTEC), and the Institute of Atmospheric Physics (IAP) of the Chinese Academy of Sciences (CAS) - to elucidate regional chemistry and the transport of $\mathrm{O}_{3}$ and aerosol in CEC (see Akimoto et al., 2010, for more detailed information on the campaign). As part of the campaign, this paper presents and discusses VOC mixing ratios observed on the summit of Mount Tai in CEC. General characteristics and correlations between selected VOCs were examined to assess their source emissions and investigate the influence of biomass burning on the region during the campaign period.

\section{Experimental}

\subsection{Sampling site}

VOC measurement using the canister sampling method were carried out at the observatory on the summit of Mount Tai $\left(36.26^{\circ} \mathrm{N}, 117.11^{\circ} \mathrm{E}, 1534 \mathrm{~m}\right.$ above sea level, located in the middle of CEC), in Shangdong province as part of the MTX 2006. Mount Tai is located just $6 \mathrm{~km}$ north of the city of Tai' an and about $60 \mathrm{~km}$ to the south of the provincial capital Jinan. It has been declared by UNESCO to be a World Heritage site. In addition to its central location in CEC, the remoteness of the site is believed to allow little influence from local anthropogenic pollution, making the site suitable for observations of regional representative air quality.

\subsection{VOC measurements}

During the campaign (2-28 June 2006), whole ambient air samples were compressed using a Teflon bellows pump (Iwaki, BA-106TN) and collected every day at approximately 14:00 LT into 6-L type canisters provided by Entech (Silonite) and Hewlett Packard (SilcoCan). These canisters are coated with fused silica allowing VOCs to remain stable for long periods of time. Sample collections were performed on the 2nd floor balcony of the observatory, where the inlet was held $1.5 \mathrm{~m}$ above the floor with a sampling duration of $2 \mathrm{~min}$. In addition to the 25 canisters used for daytime samples, 5 canisters were filled with nighttime or early morning 
ambient air samples. Analysis of the samples was performed after the canisters were shipped back to the laboratory. The analysis method was based on the premixing ratio of the air sample $(500 \mathrm{cc})$ by commercial concentrator (Entech, model 7000) coupling with gas chromatography (GC) techniques: flame ionization detector (FID) and mass spectrometry (MS) provided by Hewlett Packard model HP-6890 and HP-5973, respectively. Details on the analysis method are described elsewhere (Kato et al., 2004, 2007). In brief, after three-stage premixing ratio with three different sorbent traps (glass bead, Tenax, and cryofocusing with silcosteel tube) was carried out with specific trapping and desorption temperatures, concentrated air samples were then injected into a GC oven at an initial temperature of $-50^{\circ} \mathrm{C}$ using liquid nitrogen and heated up at two different rates $\left(5\right.$ and $\left.15^{\circ} \mathrm{C} \mathrm{min}^{-1}\right)$ to a final temperature of $150^{\circ} \mathrm{C}$. This method was applied for GC-FID and GC-MS with the use of an HP-1 column (Hewlett Packard) $(60 \mathrm{~m} \times 0.32 \mathrm{~mm} \times 1 \mu \mathrm{m})$. A different temperature setup was used with a porous layer open tubular (PLOT) column (Hewlett Packard) $(50 \mathrm{~m} \times 0.53 \mathrm{~mm} \times 15 \mu \mathrm{m})$ for GC-FID to determine mixing ratio of low carbon number VOCs $\left(\mathrm{C}_{2}-\mathrm{C}_{4}\right)$. GC-FID was specifically used to obtain hydrocarbon mixing ratios, while GC-MS was used to detect of halocarbon species. Standard gases (Enviro-Mat Ozone Precursor Mixture provided by Matheson and TO-14 of T. E. R. R. A serie provided by Takachiko) were analysed each day prior to analysis of sample to ensure accuracy of the data. The 63 VOC species derived from the analysis ranged from $\mathrm{C}_{2}$ to $\mathrm{C}_{9}$ and included alkanes (25), alkenes (19), acetylene, aromatics (7), and halocarbons including CFCs and other halogenated species (12). LOD for alkanes, alkenes, and aromatics are in the range of 1-3 pptv with accuracy of $2-13 \%$ and precision of $2-15 \%$. For halocarbon species, LOD are within the range of $0.1-0.5$ pptv with accuracy of $2-10 \%$ and precision of $1-3 \%$.

\section{Results and discussions}

\subsection{Overview of VOC mixing ratios}

\subsubsection{General characteristic of observed VOCs}

The temporal variations of selected hydrocarbon species are shown in Fig. 1a and $b$ with arrows for indication of nighttime data. Log scales were used for better clarity of the variation trends observed for different species. Statistical details of major detected VOCs during measurements are also provided in Table 1. The characteristics of an air mass with minimum local perturbation are revealed in Fig. 1a and b, where selected VOC mixing ratios - including saturated and unsaturated species - fluctuate with similar trends. In an atmosphere encountering constant local emissions, there would be dissimilar variations between each compound. This characteristic has been reported for several observations of remote
Table 1. Averaged, standard deviation (SD), median, minimum and maximum mixing ratios of major detected VOC compounds during 2-28 June 2006. Units are all in pptv.

\begin{tabular}{|c|c|c|c|c|c|}
\hline VOC & Average & $\mathrm{SD}$ & Median & Minimum & Maximum \\
\hline Ethane & 2401 & 778 & 2457 & 1092 & 3755 \\
\hline Propane & 620 & 331 & 587 & 159 & 1677 \\
\hline$i$-Butane & 157 & 87 & 146 & 19 & 398 \\
\hline$n$-Butane & 209 & 141 & 168 & 24 & 700 \\
\hline$i$-Pentane & 172 & 96 & 155 & 7 & 428 \\
\hline$n$-Pentane & 85 & 53 & 72 & 2 & 282 \\
\hline$n$-Haxane & 130 & 314 & 49 & 7 & 1687 \\
\hline$n$-Heptane & 34 & 25 & 28 & 6 & 114 \\
\hline$n$-Octane & 30 & 33 & 25 & 2 & 187 \\
\hline$n$-Nonane & 18 & 21 & 11 & 1 & 104 \\
\hline Acetylene & 1609 & 969 & 1545 & 154 & 3819 \\
\hline Ethene & 994 & 723 & 875 & 74 & 3555 \\
\hline Propene & 110 & 47 & 88 & 31 & 201 \\
\hline 1-Butene & 16 & 10 & 15 & ND & 42 \\
\hline 1,3-Butadiene & 3 & 2 & 3 & ND & 8 \\
\hline Benzene & 641 & 349 & 672 & 36 & 1274 \\
\hline Toluene & 205 & 123 & 194 & 12 & 558 \\
\hline Ethylbenzene & 61 & 84 & 43 & 3 & 475 \\
\hline$p, m$-Xylene & 35 & 73 & 17 & 2 & 413 \\
\hline Styrene & 7 & 11 & 4 & 1 & 58 \\
\hline$o$-Xylene & 81 & 68 & 63 & 9 & 350 \\
\hline Isoprene & 173 & 184 & 116 & 0 & 768 \\
\hline $\mathrm{C}_{2} \mathrm{Cl}_{4}$ & 8 & 13 & 5 & 2 & 74 \\
\hline $\mathrm{CH}_{3} \mathrm{Cl}$ & 990 & 374 & 902 & 549 & 1998 \\
\hline $\mathrm{CH}_{3} \mathrm{Br}$ & 16 & 6 & 14 & 8 & 36 \\
\hline
\end{tabular}

$* \mathrm{ND}=$ not detected

areas (Sharma et al., 2000; Kato et al., 2004). Owing to intensive photochemical removal by $\mathrm{OH}$ radicals during the summertime (Swanson et al., 2003) and the inverse relationship between $\mathrm{OH}$ reaction rates and VOC carbon numbers (Kato et al., 2004), compounds with higher carbon numbers showed lower mixing ratios compared to those with lower carbon numbers. Therefore, the averaged mixing ratios for saturated species showed a higher value of lower carbon number species - i.e., ethane, propane, $n$-butane, $n$-pentane were $2401,620,209$, and 85 pptv, respectively. The $n$-hexane averaged mixing ratio (130 pptv) was slightly higher than for $n$-pentane. Measurements at PRD by L. Y. Chan et al. (2006) found that $n$-hexane, used mostly for construction coating solvents and paint thinners, was the most abundant VOC in industrial area ambient air; this has been attributed to the rapid industrialization and economic growth in suburban and rural areas. Judging from weak enhancements of $n$-hexane throughout the period and its relatively short lifetime of several hours, air masses sampled here were insignificantly impacted from industrial emission. A similar trend was also found for industrial tracer species: toluene, and the industrial tracer specie, $\mathrm{C}_{2} \mathrm{Cl}_{4}$, as shown in Fig. 1b. This also supports the belief that the air masses were not affected from 

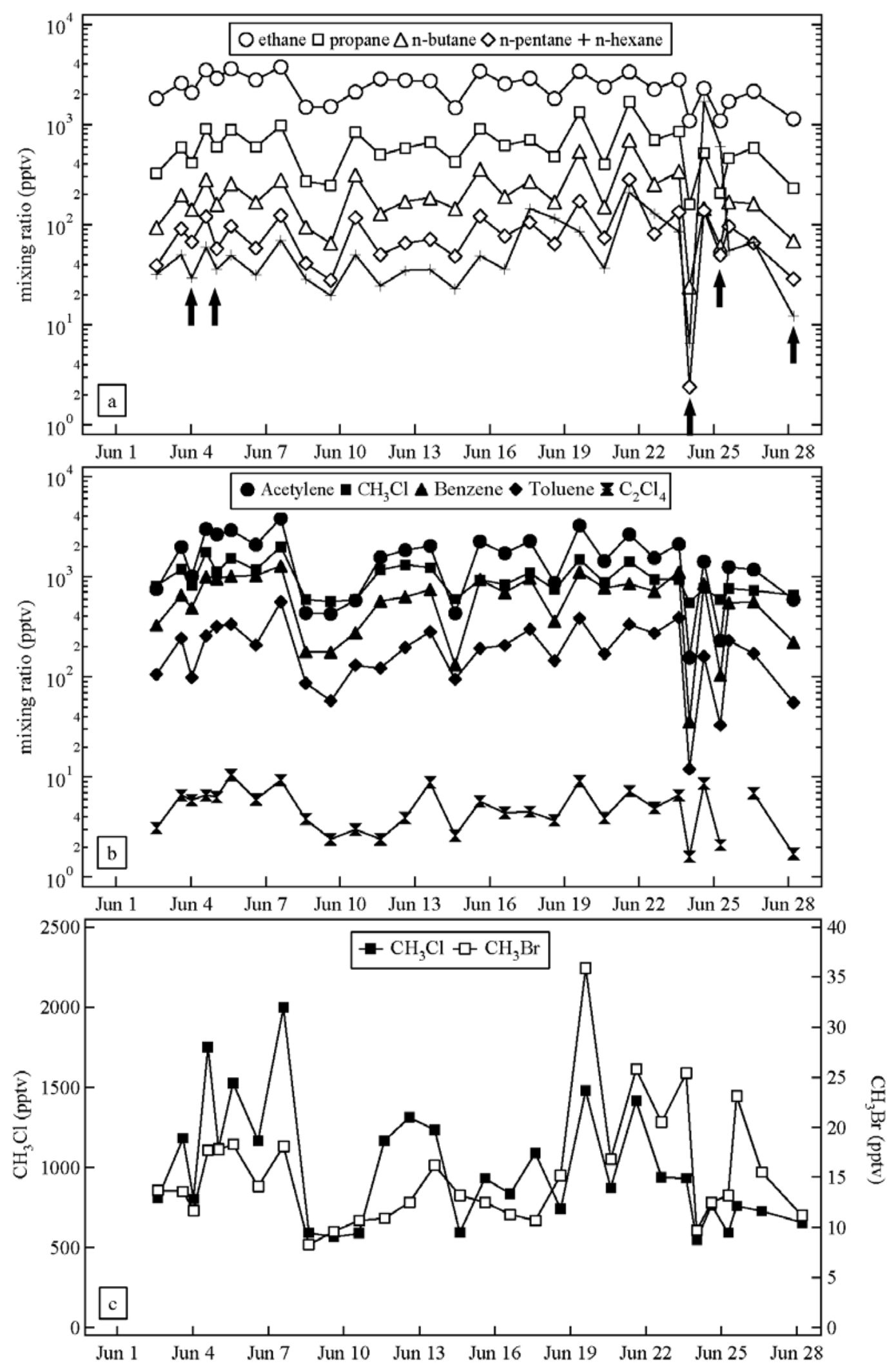

Fig. 1. Mixing ratios of selected hydrocarbons from measurement during 2-28 June 2006: (a) ethane, propane, $n$-butane, and $n$-pentane, (b) acetylene, benzene, toluene, and $\mathrm{C}_{2} \mathrm{Cl}_{4}$, (c) $\mathrm{CH}_{3} \mathrm{Cl}$ and $\mathrm{CH}_{3} \mathrm{Br}$. Arrows, in (a), indicated nighttime observations. 
industrial emission. Significantly lower concentrations were found during the night of 23 and 24 June. It can possibly be explained by the shift in boundary layer height (further discussion in Sect. 3.2) and the arrival of relatively clean air hovering above boundary layer.

Figure 1c shows the temporal variations of $\mathrm{CH}_{3} \mathrm{Cl}$ and $\mathrm{CH}_{3} \mathrm{Br}$. Spikes of these species were found throughout the period. The mixing ratios of these species were well above background mixing ratios for the earth's atmosphere with occasional peaks; $\mathrm{CH}_{3} \mathrm{Cl}$ has been reported to have a mixing ratios of 530-560 pptv, while $\mathrm{CH}_{3} \mathrm{Br}$ mixing ratios has been reported to be around 8-9 pptv (World Data Center for Greenhouse Gases, 2008). The considered background mixing ratios of $\mathrm{CH}_{3} \mathrm{Cl}$ and $\mathrm{CH}_{3} \mathrm{Br}$ were also observed occasionally and mostly in the latter half of the campaign. These species are used as an indicator of biomass/biofuel burning emissions (Andreae and Merlet, 2001); thus, this region is suggestively sporadically affected by emissions from biomass/biofuel burning.

\subsubsection{Comparison with other Chinese sites}

To compare VOC mixing ratios observed at other Chinese sites, Table 2 shows 12 major VOCs observed for various site characteristics: remote (Mount Jianfeng), rural (Mount Dinghu, Lin'an, Tai O, Tap Mun, Hok Tsui), suburban (Panyu, Tung Chung, Yuen Long, T3), urban (Guangzhou, Central/West Hong Kong, Hong Kong road side, T2), and industrial (T1). Although several factors affect the observed VOC mixing ratios and should be taken into account - e.g. season, sampling method, and sampling time - average mixing ratios with one standard deviation were used to depict an overview of the ambient VOC levels in Chinese measurement sites. It should be noted that VOCs means and SD used for comparison are derived from whole observation including daytime and nighttime measurements. Despite an influence from significantly lower mixing ratios of nighttime data on the values reported for Mount Tai, values for daytime only data are within 10 percent increase from total means and SD (see Table S1 of the supplement material: http://www.atmos-chem-phys.net/10/1269/ 2010/acp-10-1269-2010-supplement.pdf).

VOCs at Mount Tai showed higher mixing ratios compared to another remote site at Mount Jianfeng. This is likely due to the more remoteness of Mount Jianfeng. The mixing ratios of ethane observed at various sites in China were relatively similar despite different site characteristics. As the lifetime of ethane is more than several months, this allows the specie to be transported and dispersed over a wide range of areas. Butane and pentane, which generally emit from vehicular emission and gasoline evaporation, revealed significantly lower mixing ratios at Mount Tai compared to other rural and suburban sites. The influence of vehicular emissions is generally determined using the ratio between benzene and toluene (B/T). A value close to 0.6 has been reported as characteristic of traffic-related emissions in 43 Chinese cities (Barletta et al., 2005). The roadside measurement in Hong Kong reported a value of 0.2 (So and Wang, 2004) similar to the $\mathrm{B} / \mathrm{T}$ ratio observed for the Mexico City Metropolitan Area (Velasco et al., 2007). B/T ratios obtained during this research showed much larger values (3.24 \pm 0.97$)$, indicating that the influence from vehicular emissions is insignificant at this site. For combustion-related compounds - acetylene and benzene - their mixing ratios fell within the values reported at rural sites; however, these were much higher compared to another remote site. Barletta et al. (2005) reported remarkably high acetylene mixing ratios during winter observations of cities neighboring Mount Tai, including Jinan (23.6 ppbv) and Jining (7.9 ppbv). This is likely due to the impact of biomass burning emissions and is scrutinized in a later section. Biogenic activity, indicated by isoprene mixing ratios, at Mount Tai ( $173 \pm 184$ pptv) was lower than that at Mount Jianfeng $(480 \pm 470 \mathrm{pptv})$. Nonetheless, this is not necessarily true for observations of suburban, urban, and industrial areas where vehicular sources can contribute as much as $1 \mathrm{ppbv}$ to ambient isoprene (Lee and Wang, 2006).

\subsection{Observation of regional background}

One advantage of having a measurement site on the summit of a mountain with elevated high above the plain area is the possibility of capturing air masses circulating in the free tropospheric layer. Observations at Waliguan station, a remote site in the Qinghai-Tibetan plateau with a height of $3810 \mathrm{~m}$, revealed a feature of maximum $\mathrm{O}_{3}$ concentration during summer (Zhu et al., 2004) which was later discussed to attribute potentially to frequent convection occurring in the area (Ma et al., 2005). The Mount Tai observatory provides a similar seasonal variation despite its lower altitude. Nonetheless, significant difference was found for diurnal variation of the two sites (B. Zhu, personal communication, 2009) in which convection alone cannot result in systematic higher $\mathrm{O}_{3}$ concentrations during the daytime and lower concentrations at night. Diurnal variation of $\mathrm{O}_{3}$ at Mount Tai was attributed to photochemical reaction (Kanaya et al., 2009). Another reasonable explanation proposes here for VOC mixing ratio is the shift in boundary layer height. Shown in Fig. 2a and b are box plots distinguishing between daytime and nighttime (including early morning) data for alkanes, acetylene, and aromatics species. Log scales were used for the mixing ratio axis to make the trend more visible. The nighttime box plots were derived from limited data. Nevertheless, the daytime data apparently reveals higher mixing ratios than the nighttime data for all selected VOCs. The differences range from around $50 \%$ for alkanes to more than $70 \%$ for aromatic species. 
Table 2. Comparison of selected VOCs from measurement at Mount Tai and other Chinese sites: averaged mixing ratio \pm 1 SD.

\begin{tabular}{|c|c|c|c|c|c|c|c|c|c|c|c|c|c|c|c|c|}
\hline $\begin{array}{l}\text { VOCs } \\
\text { Type }\end{array}$ & $\begin{array}{r}\text { Mt.Tai } \\
\text { Re }\end{array}$ & $\mathrm{JM}^{\mathrm{a}}$ & $\mathrm{DM}^{\mathrm{a}}$ & $\mathrm{LN}^{\mathrm{b}}$ & ${ }_{\text {Rural }}^{\mathrm{TO}^{\mathrm{c}}}$ & $\mathrm{TM}^{\mathrm{d}}$ & $\mathrm{HT}^{\mathrm{e}}$ & $P Y^{\mathrm{a}}$ & $\begin{array}{r}\mathrm{TC}^{\mathrm{d}} \\
\text { Sub }\end{array}$ & $\mathrm{YL}^{\mathrm{d}}$ & $\mathrm{T} 3^{\mathrm{f}}$ & $\mathrm{GZ}^{\mathrm{a}}$ & $\begin{array}{l}\mathrm{C} / \mathrm{W}^{\mathrm{d}} \\
\text { Urba }\end{array}$ & $\mathrm{HK}^{\mathrm{g}}$ & $\mathrm{T} 2^{\mathrm{f}}$ & $\begin{array}{c}\mathrm{T}^{\mathrm{f}} \\
\text { Industrial }\end{array}$ \\
\hline Ethane & $2401 \pm 778$ & $1510 \pm 400$ & $2720 \pm$ & $2530 \pm 400$ & $2122 \pm 990$ & $1787 \pm 271$ & $2368 \pm 508$ & $2710 \pm 950$ & $1724 \pm 274$ & $2116 \pm$ & $1400 \pm 600$ & $3900 \pm 1170$ & $1829 \pm 263$ & - & $1800 \pm 600$ & $2300 \pm 1300$ \\
\hline Propa & $0+331$ & $320+190$ & $2030 \pm 940$ & $80 \pm 380$ & $2048 \pm 2159$ & $861 \pm 142$ & $814 \pm 307$ & $4270 \pm 2200$ & $1196 \pm 266$ & $2545 \pm 398$ & $2100 \pm 1700$ & $11290 \pm 5690$ & $1595 \pm 218$ & 4010 & $2500 \pm 1400$ & $3700 \pm 2500$ \\
\hline$i$-Butane & $157 \pm \varepsilon$ & \pm & $0 \pm 64$ & 0 & $804 \pm 928$ & $1 \pm 57$ & $221 \pm 117$ & $1870 \pm 101$ & $502 \pm 102$ & $1461 \pm 184$ & $800 \pm 600$ & $4480 \pm 2310$ & $899 \pm 98$ & 2870 & $1000 \pm 500$ & $1600 \pm 800$ \\
\hline$n$-Butane & $209 \pm 141$ & $100 \pm$ & 1 & 30 & $1638 \pm 21$ & $592 \pm 96$ & $326 \pm 169$ & $2980 \pm 1640$ & 12 & $2625 \pm 356$ & $1300 \pm 1000$ & $0 \pm 3210$ & $1464 \pm 160$ & 6530 & $1500 \pm 900$ & $2600 \pm 1700$ \\
\hline & & & & & & 365 & - & & & 11 & & & & 4480 & \pm 700 & 500 \\
\hline$n$-Pet & & & & & & & 48 & & & & & & 32 & 1710 & $500 \pm 400$ & \\
\hline Ethen & & & & & 167 & & $498 \pm$ & & 59 & $2674=$ & 2000 & \pm 4280 & $1465 \pm 195$ & - & $2600 \pm 1300$ & 3800 \\
\hline Prope & & & & & & & & & & & & & & - & \pm 300 & $=800$ \\
\hline Acetylene & 160 & 9 & 430 & 0 & 277 & 1365 & 1402 & & 176 & 2872 & 700 & & 1950 & - & 00 & 3000 \\
\hline Benze & & & & & & & & & & & & & 41 & 1580 & \pm 1100 & 700 \\
\hline Toluene & tha & $90 \pm 60$ & $3090 \pm 1790$ & $1600 \pm 1240$ & $5670 \pm 7128$ & $1033 \pm 239$ & $540 \pm 482$ & $9930 \pm 5590$ & $2265 \pm 689$ & $4340 \pm 871$ & $7300 \pm 5400$ & $0020 \pm 4690$ & $2765 \pm 421$ & 8240 & $500 \pm 11600$ & $13500 \pm 11800$ \\
\hline Isoprene & $173 \pm 184$ & $480 \pm 470$ & $120 \pm 800$ & $740 \pm 910$ & $427 \pm 727$ & $334 \pm 81$ & 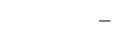 & $180 \pm 100$ & $148 \pm 30$ & $192 \pm 24$ & $500 \pm 700$ & $270 \pm 140$ & $178 \pm 46$ & 650 & $400 \pm 200$ & $600 \pm 300$ \\
\hline
\end{tabular}

Unit: pptv

a Tang et al., 2007: April 2005 - JM, Mt. Jianfeng; GZ, Guangzhou; PY, Panyu; DM, Mt. Dinghu

b Guo et al., 2004: June 2001 - LN, Lin'an

${ }^{c}$ Guo et al., 2006: August 2001-December $2002-$ TO, Tai O

d Guo et al., 2007: September 2003 to August 2003 - TM, Tap Mun; C/W, Central/Western; TC, Tung Chung; YL, Yuen Long

e Wang et al., 2003: February 2001 to April 2001 - HT, Hok Tsui (rural area in Hong Kong)

${ }^{f}$ L. Y. Chan et al., 2006: August 2000 to September 2000 - PRD (T1, industrial; T2, mixed industrial and urban; T3, mixed industrial and suburban/rural)

g So and Wang, 2004: November 2000 to October 2001 - HK, Hong Kong (road side) 

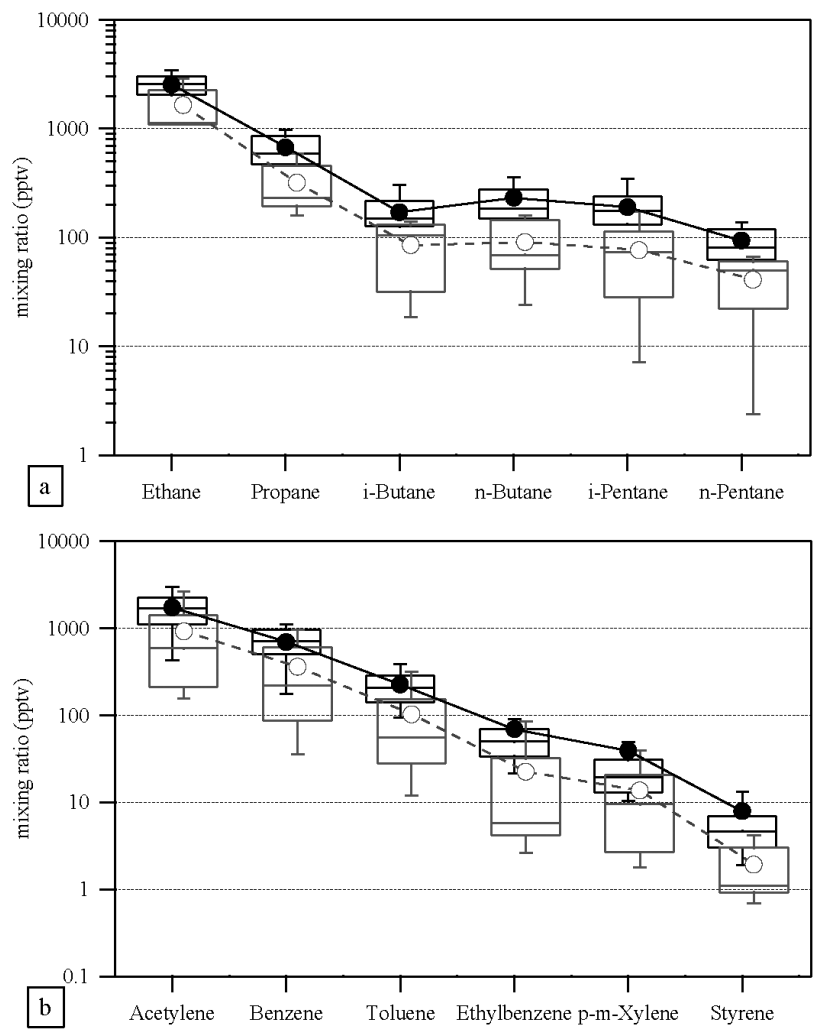

Fig. 2. Box plots of VOCs mixing ratios, alkanes (a), acetylene, and aromatics (b). Log scale is used in order to make all data visible. Data were divided into two set; daytime data (black); nighttime and early morning data (grey). The 10-th percentile, 25-th percentile, median, average, 75-th percentile, and 90-th percentile are shown as lower bar, lower edge, line, circle with line, upper edge, and upper bar, respectively.

Airborne measurement campaigns were extensively carried out in the East Asia area endeavor to systematically study the intercontinental transport of anthropogenic air pollutants (e.g. Hoell et al., 1996, 1997, 1999; Jacob et al., 2003; Parrish et al., 2004). Vertical profiles of atmospheric trace species reported - from observations and model calculations, during the Pacific Exploratory Mission (PEM), the Transport and Chemical Evolution over the Pacific (TRACEP), and the Pacific Exploration of Asian Continental Emission (PEACE) campaigns - revealed that high mixing ratios are found in measurements at relatively lower altitudes and that mixing ratios decrease with increasing in altitude (Blake et al., 1996, 1997, 2001, 2003; Kondo et al., 2004; Takigawa et al., 2005). Blake et al. (1997) showed distinct differences in ethane, acetylene, propane, and benzene levels - occasionally ranged up to factor of two - for measurements at altitude ranges of $0-2 \mathrm{~km}$ and $2-7 \mathrm{~km}$, which correspond to planetary boundary layer (PBL) and free troposphere (FT), respectively; these measurements were taken during the PEM-West A (late summer) and B (late winter) campaigns. Similar characteristics were also found for

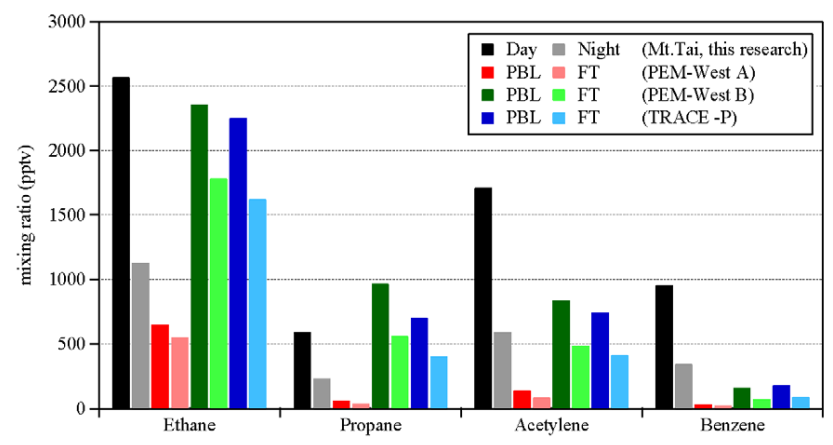

Fig. 3. Bar chart for median VOCs mixing ratios observed in Planetary Boundary Layer (PBL) and Free Troposphere (FT) during the Mount Tai campaign, PEM-West A (late summer) and B (late winter) derived from Blake et al. (1997), and TRACE-P (winter-spring) derived from Blake et al. (2003).

the TRACE-P (winter-spring) campaign (Blake et al., 2003). It should be noted that Talbot et al. (1997) also suggested greater continental and anthropogenic impact during PEMWest B than PEM-West A. This can also be the case for TRACE-P as both campaign conducted during the winterspring season when the continental outflow is at its maximum (Suthawaree et al., 2008). In Fig. 3, the mixing ratios of ethane, acetylene, and benzene - obtained for PBL show higher mixing ratios at Mount Tai than those for airborne campaigns; this is most likely due to the closer distance to emission sources. In addition, hovering over the west Pacific for airborne measurement also subjects air sample to the additional abstraction of VOC hydrogen atoms by halogen atoms, decreasing the mixing ratios (Jobson et al., 1994). The propane level indicates a dissimilar trend, in which PEM-West B and TRACE-P data reveal higher mixing ratios than that for Mount Tai. Although there is no solid explanation for this trend at this stage, this is not unexpected, as LPG usage in China is substantially insignificant in remote areas, where biofuel is a regular energy source in residential sectors (Streets et al., 2001; Woo et al., 2003; Fernandes et al., 2007) and estimated to account for approximately 50\% of total usage in Asia (Streets and Waldhoff, 1998).

A comparison between FT data observed at Mount Tai and airborne revealed comparable mixing ratios. For acetylene and benzene level, FT data at Mount Tai showed a higher mixing ratio than all airborne data. The opposite feature was found for ethane and propane, where data from PEMWest B and TRACE-P showed higher mixing ratios. This interesting result can be explained in a similar manner to PBL data, as LPG is not a main stream fuel in remote areas. Meanwhile, biofuel, which is a significant emission source for acetylene and benzene, is a more common energy source. It should be noted that FT data at the site was derived from a small data set (five canisters from nighttime measurement), which may have been affected by encounters with very unique air masses with low ethane and propane. 

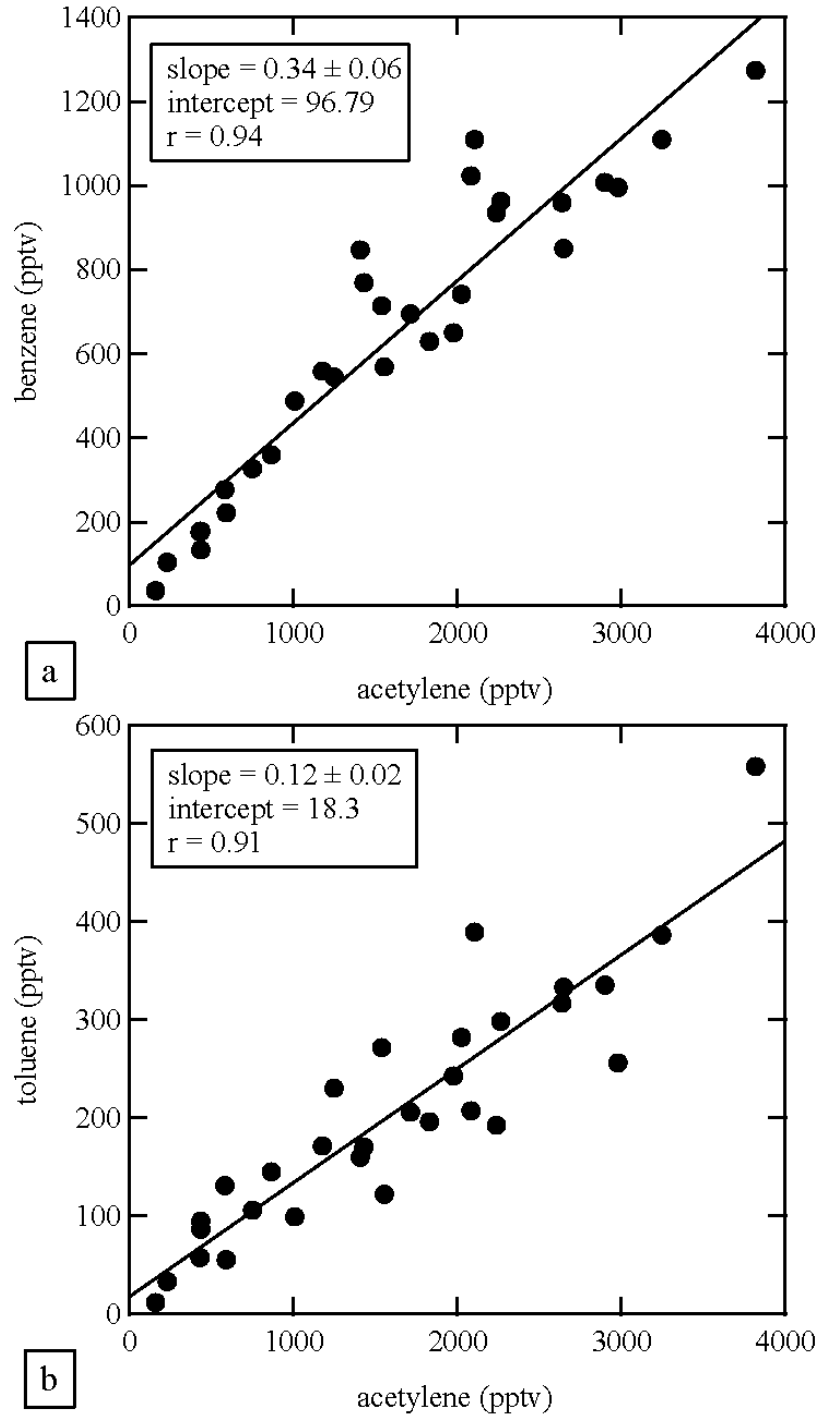

Fig. 4. Correlation plots between benzene and acetylene (a) and between toluene and acetylene (b) observed during the whole VOC measurements period. The lines are shown for linear least square fit. Slopes and correlation coefficients are annotated. Slopes are shown with associated error of $99 \%$ confidence.

Nonetheless, comparable mixing ratios of proposed FT air observed at Mount Tai and other airborne results strongly suggest that this site potentially has very useful feature of being able to monitor free troposphere or regional background air quality.

Differences between PBL and FT mixing ratios from observations at the site indicated an inevitable effect driven by the vertical movement of PBL. During the campaign, the PBL height was calculated from meteorological conditions to reach a maximum of around $4000 \mathrm{~m}$ at midday and a minimum of $200 \mathrm{~m}$ during the night to early morning period, with averages of 2200 and $600 \mathrm{~m}$, respectively, for the month of June (M. Takigawa, personal communication,
2007). Pollutants tend to survive longer in FT than PBL due to lower chemical destruction and wet removal rate. However, the influence from regional emissions in the PBL is believed to be much greater at the site relative to long-range transport from other regions. In other words, the FT mixing ratios can be regarded as corresponding to the regional background levels. Given these facts, the following two points are validated: (1) grouping of the nighttime and early morning data, and (2) a comparison between mixing ratios of trace species in PBL and FT to provide calculations for the enhancement of VOCs owing to anthropogenic activities. Unfortunately, due to inadequacy in the data set size, the differences found in this research are not likely to represent regional enhancement. However, this study uncovered valuable features of the observatory, which will be very useful and convenient for future regional air quality exploration.

\subsection{Interspecies correlations and comparison with emission inventories}

Because absolute mixing ratios of VOCs are known to vary largely with space and time, the ratio between trace species is believed to provide important regional air quality information and source-specific emission signatures. The enhancement ratio (ER) of specie $X$ with respect to specie $Y$ is given as:

$\operatorname{ER}(X / Y)=\frac{\Delta[X]}{\Delta[Y]}=\frac{[X]_{\text {ambient }}-[X]_{\text {background }}}{[Y]_{\text {ambient }}-[Y]_{\text {background }}}$

where blankets indicate mixing ratios. To avoid the complication of determining the background level by using a slope from the correlation plot instead to obtain ER, Jost et al. (2003) stated two requirements: a fast measurement technique and a large data set. Nonetheless, as previously mentioned, our observation tends to capture a representative regional air quality, thus, it can be assumed that the ER obtained at this site provides general information on the emission characteristics of this region.

Acetylene emissions are usually associated with the incomplete combustion of different types of fossil fuels (Blake and Rowland, 1995) as well as the burning of biomass (de Gouw et al., 2004). Sources of benzene in China are quite similar to those for acetylene; however, they are different in percent contribution for different emission sources (Liu et al., 2008b). The correlation plot between acetylene and benzene, in Fig. 4a reveals a strong correlation between these two species, with a slope of 0.34 and linear correlation coefficient $(r)$ of 0.94 . When compared to the ER of 0.29 and 0.11 for stationary (industrial and residential sources including biofuel) and transport sources, respectively - estimated from China's NMVOC emission inventory for the year 2000 (Klimont et al., 2002) - and the value of 0.13 reported by Barletta et al. (2005) for traffic-related cities, the slope shows that stationary sources have the greatest influence at this site. In an environment where traffic emission 

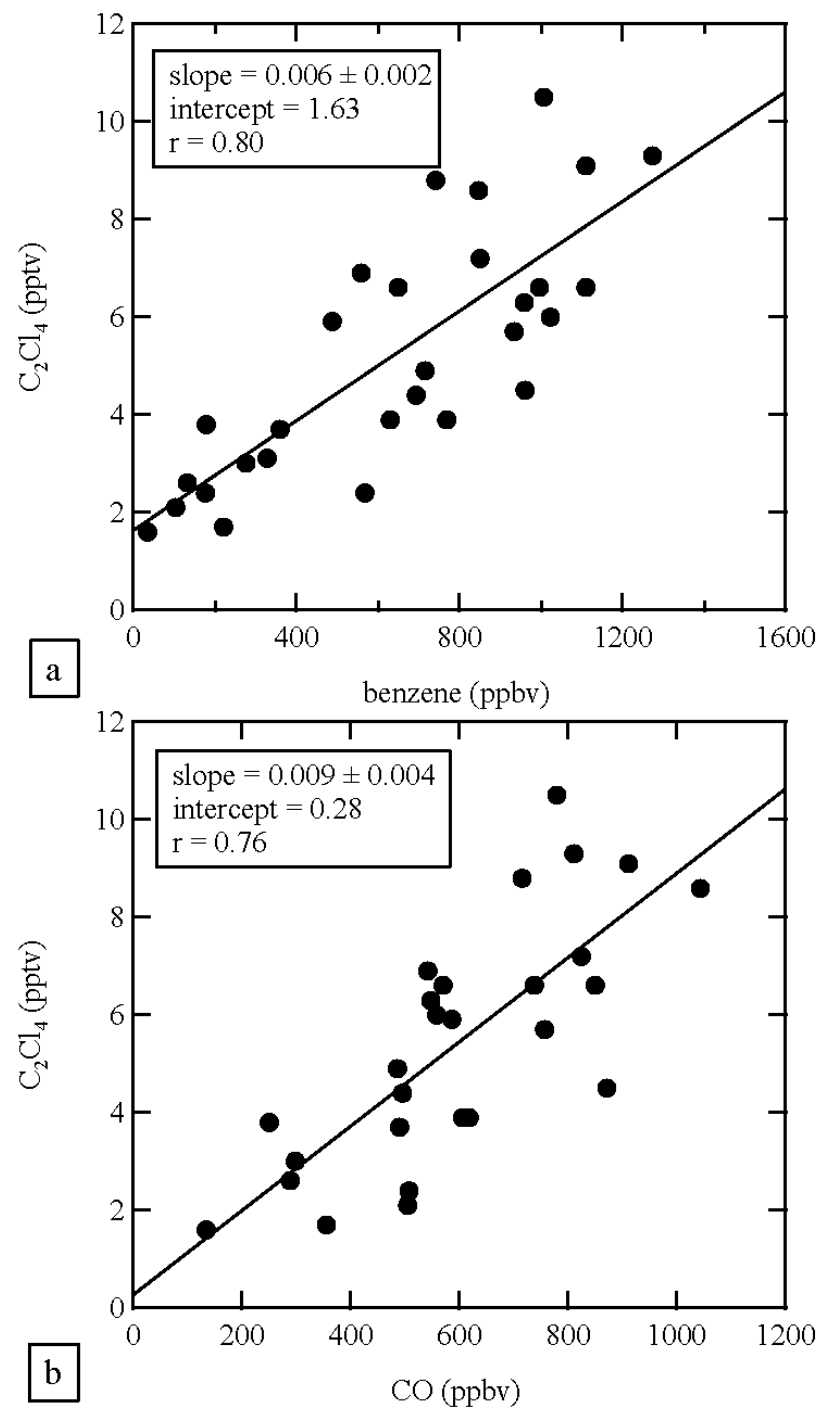

Fig. 5. Correlation plot between $\mathrm{C}_{2} \mathrm{Cl}_{4}$ and benzene is shown in (a). Plot between $\mathrm{C}_{2} \mathrm{Cl}_{4}$ and $\mathrm{CO}$ is also shown in (b). The lines are shown for linear least square fit. Slopes and correlation coefficients are annotated. Slopes are shown with associated error of $99 \%$ confidence.

is insignificant, toluene most likely comes from many activities, including stationary sources. Correlation plot between toluene and acetylene in Fig. $4 \mathrm{~b}$ gives a slope of 0.12 , which is very similar to the ER for stationary combustion $(0.12)$ and much lower than the ER for transport section (0.37; Klimont et al., 2002, and 0.24; Barletta et al., 2005). These results suggest that this site is greatly affected by emissions from stationary sources rather than vehicular emissions.

Tetrachloroethene $\left(\mathrm{C}_{2} \mathrm{Cl}_{4}\right)$ is widely known as an industrial signature VOC (McCulloch et al., 1999) and has been used by several authors (Blake et al., 1997, 2003; de Gouw et al., 2004) due to its usage in and potential dispersion from a wide variety of industrial activities. The reasonably strong
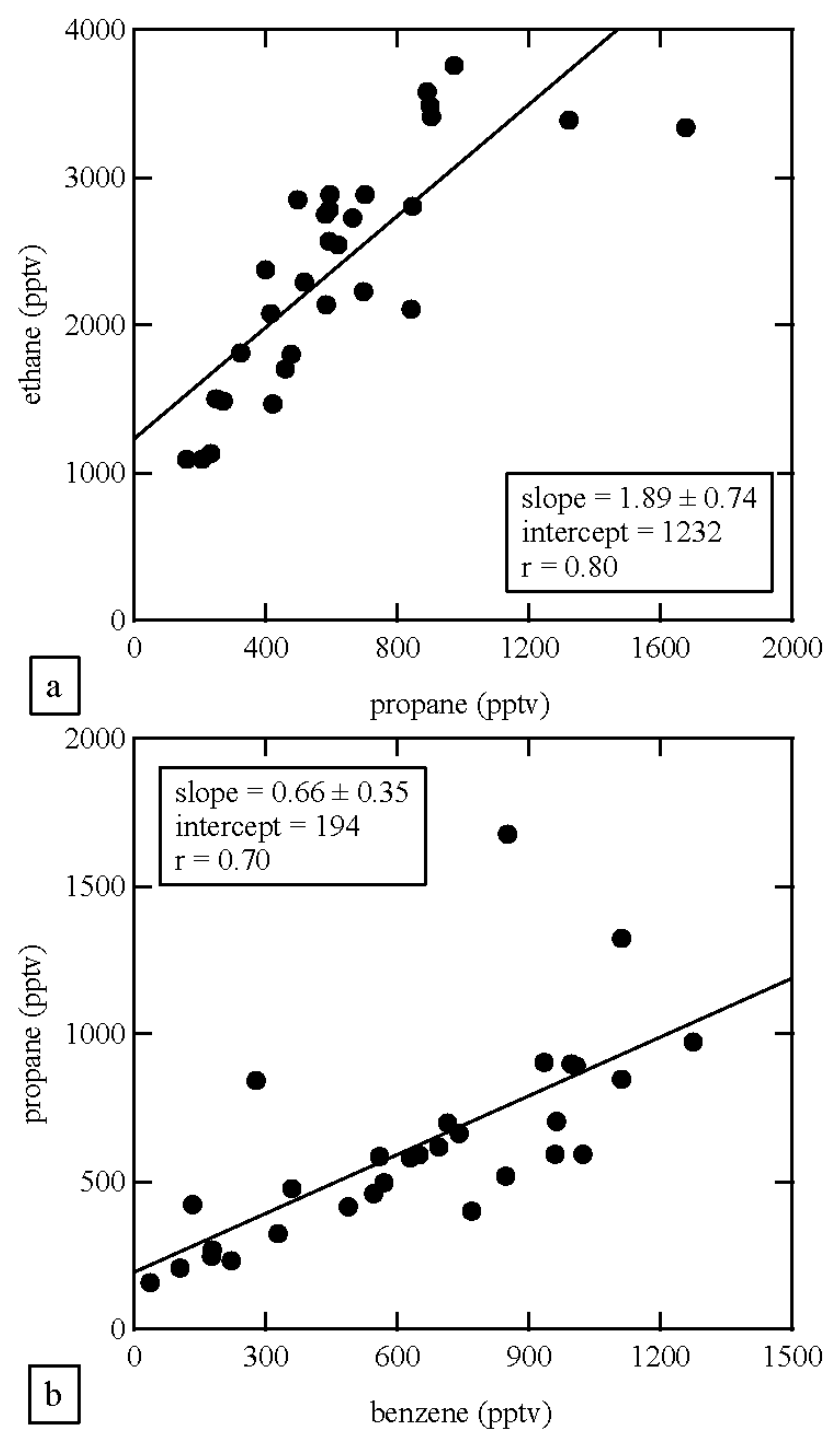

Fig. 6. Correlation plots between (a) ethane and propane, and (b) propane and benzene. The line show linear least square fit. Slopes and correlation coefficients are annotated. Slopes are shown with associated error of $99 \%$ confidence.

correlation between $\mathrm{C}_{2} \mathrm{Cl}_{4}$ and benzene $(r=0.80$ and slope of 0.006), shown in Fig. 5a, can be interpreted as an indicator of the impact from industrial emissions. However the slope is much lower than the ratios observed for Shanghai (0.016) and Qingdao (0.024) from airborne observations coupled with trajectory analysis for industrialized provinces during TRACE-P (Guttikunda et al., 2005); this implies that the influence of industrial exhaust is insignificant. Moreover, using data from the Asian emission inventory (Streets et al., 2003a) and the reactive chlorine emission inventory (McCulloch et al., 1999) for $\mathrm{CO}$ and $\mathrm{C}_{2} \mathrm{Cl}_{4}$, respectively, allows for the estimation of $\Delta \mathrm{C}_{2} \mathrm{Cl}_{4} / \Delta \mathrm{CO}$ in China as a whole country. Despite large uncertainties associated with emission 


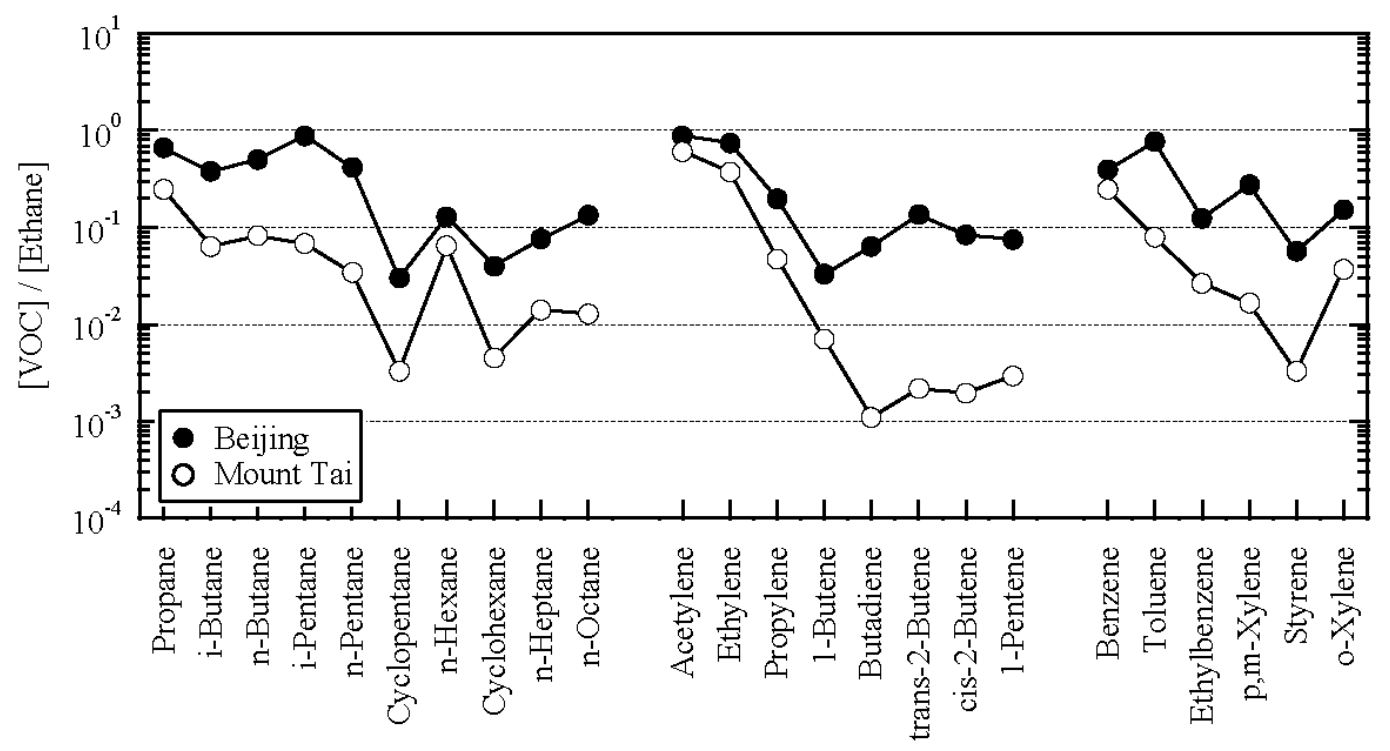

Fig. 7. Normalized by ethane ratios for selected VOCs observed at Mount Tai and Beijing (data for Beijing is obtained from canister sampling collected near the city center at 12:00 on 20 November 2005). The ratios are shown in log scale.

inventories, the value of 0.006 agreed fairly well with the value of $0.009(r=0.76)$ obtained at this site (Fig. 5b), thus, corroborating a decent capture of the regional representative air mass.

More recent regional emission estimates for Asia, extensively evaluated using observation data (Carmichael et al., 2003), showed significant variation in emission ratios between several NMHCs from different source categories. From the estimation, the value of ethane/propane for CEC ranged from less than 1.0 to 3.0; the value at Mount Tai was 1.5-2.0. The emission factor ratios for various source sectors indicate that the estimated values for local biomass burning, biofuel combustion, and transportation were 1.9, 2.3, and 0.5 , respectively. The slope between ethane and propane - 1.89, shown in Fig. 6 a - obtained in this study falls between the inventoried ranges for areas with biomass/biofuel burning as important emission sources. Propane and benzene have a similar $\mathrm{OH}$ rate constant and are inefficiently removed by wet deposition, resulting in very similar lifetime ( 9.4 days for propane and 10 days for benzene; Atkinson, 2000). The regional distribution of propane/benzene was estimated to be less than 1.6 for the Mount Tai area. The slope of the observed propane/benzene was found to be moderately lower (0.66 in Fig. 6b). The markedly gentle slope likely owes to an excess source of benzene, attributed to biomass burning (Carmichael et al., 2003). The influence from biomass/biofuel burning is explored in more detail in the following section.

\subsection{Influence of biomass and biofuel burning}

Biomass/biofuel burning emissions are known to have contributed a considerable amount of $\mathrm{CO}$ and VOCs into the atmosphere; these can perturb atmospheric chemistry, especially in the formation of greenhouse gases and tropospheric ozone (Streets and Waldhoff, 1999; Jain et al., 2006), due to rapid uplifting into the free troposphere and the long lifetime of these species (Elliott et al., 2003; Bertschi et al., 2004; de Gouw et al., 2004). Lü et al. (2006) recently reported the addition of $2.71 \mathrm{Tg}$ of $\mathrm{CO}$ and $0.113 \mathrm{Tg}$ of NMHCs to the atmospheric carbon cycle from fire disturbance. China contributes $25 \%$, or approximately $180 \mathrm{Tg}$, of the total annual amount of biomass burned in Asia; "open burning" includes grassland, forest, and crop residue (Streets et al., 2003b), with more than $110 \mathrm{Tg}$ or $60 \%$ attributed to crop residue burning. The report also included an estimation of $460 \mathrm{Tg}$ of biomass used annually as "biofuel," which includes fuelwood, agricultural residues, and dried animal waste. An inventory of biofuel use in Asia for the year 1990 indicated that 24\% of the total fuel usage in China is biofuel (Streets and Waldhoff, 1998), which accounts for $45 \%$ of the total biofuel usage in Asia. Biofuel is extensively used in central and east China (Woo et al., 2003), where Mount Tai is located. Moreover, the burning of crop residues such as wheat in late May and rice in autumn has also been frequently observed (Wang et al., 2002). More recent research by Liu et al. (2008c) also indicated $14.3 \pm 8.2$ percent attribute to biomass burning on ambient VOCs. These facts suggest large amounts of anthropogenic emissions in China, owing to biomass burning and biofuel usage, which could have had a significant influence on observations at the site during the campaign period. 
The ethane normalized mixing ratio distribution (Fig. 7) can be useful for a direct comparison of source characteristics between China's urban and remote areas. Beijing was selected for this purpose as it is one of the biggest and most developed cities in China and relatively closer to Mount Tai compared to other Chinese megacities. The VOC mixing ratios for Beijing were obtained from one canister sampling collected near the city center at 12:00 on 20 November 2005 . The figure depicts what we would expect, as the ratio at Mount Tai is lower due to there being no significant emission source near observatory. It is interesting to see that although the ratios of major alkanes and alkenes to ethane are much lower for the observation at Mount Tai, the distribution profile is noticeably similar. Exception was found for 1,3-butadiene. This is in contrast with the ratios for acetylene and aromatic species. The normalized values of acetylene, ethene, and benzene were found to be $0.61,0.37$, and 0.25 , respectively; these are relatively comparable to those observed at Beijing, which were $0.88,0.74$, and 0.39 , respectively. The profile which shown high ratios of combustion related species without significant enhancement of ratios of vehicular emission indicators such as toluene and $i$-pentane suggests that the excess sources of these species at Mount Tai are associated with biomass/biofuel burning.

$\mathrm{CH}_{3} \mathrm{Cl}$ and $\mathrm{CH}_{3} \mathrm{Br}$ are produced predominantly during smoldering conditions and are commonly used as biomass burning tracers (Blake et al., 1996; Andreae et al., 1996). Analysis on source apportionment by Liu et al. (2008b) also indicated that $\mathrm{CH}_{3} \mathrm{Cl}$ is one of the major species emitted from biomass burning at the PRD. $\mathrm{CH}_{3} \mathrm{Br}$ is also anthropogenically emitted from fumigation (Blake et al., 1996) and vehicular emission for car using leaded gasoline (Thomas et al., 1997). Both also play a significant role in the depletion of stratospheric ozone, as they account for a relatively large portion of chlorine and bromine flux in the stratosphere (Andreae et al., 1996). The ER of these methyl halides with respect to $\mathrm{CO}$ is widely used for both qualitative and quantitative analysis of VOC emissions from biomass burning for both point sources and regionally (e.g. Andreae et al., 1996; Blake et al., 1996, 1997; Jost et al., 2003; Shirai et al., 2003; Simpson et al., 2007); CO is known to be co-emitted with VOCs at all stages of incomplete combustion. The correlation plot between methyl halides and $\mathrm{CO}$ gives slopes of 1.07 and 0.014 with correlation coefficients of 0.61 and 0.51 (Fig. 8a and b) for $\mathrm{CH}_{3} \mathrm{Cl}$ and $\mathrm{CH}_{3} \mathrm{Br}$, respectively. These values do not differ significantly from savanna fire studies, which showed values of $0.31-0.95$ for $\Delta \mathrm{CH}_{3} \mathrm{Cl} / \Delta \mathrm{CO}$ and 0.0059-0.0106 for $\Delta \mathrm{CH}_{3} \mathrm{Br} / \Delta \mathrm{CO}$ (Blake et al., 1996; Andreae et al., 1996; Shirai et al., 2003). Adopted from emission factors provided by Andreae and Merlet (2001), the ratios for $\Delta \mathrm{CH}_{3} \mathrm{Cl} / \Delta \mathrm{CO}$ were found to be $0.30-1.28,0.20$ 0.83 , and $0.60-2.29$ for savanna and grassland, biofuel burning, and agricultural residues, respectively. It should be noted that the upper and lower limiting values were calculated using the mean $\pm \mathrm{SD}$ for $\mathrm{CH}_{3} \mathrm{Cl}$ and $\mathrm{CO}$ data, except for
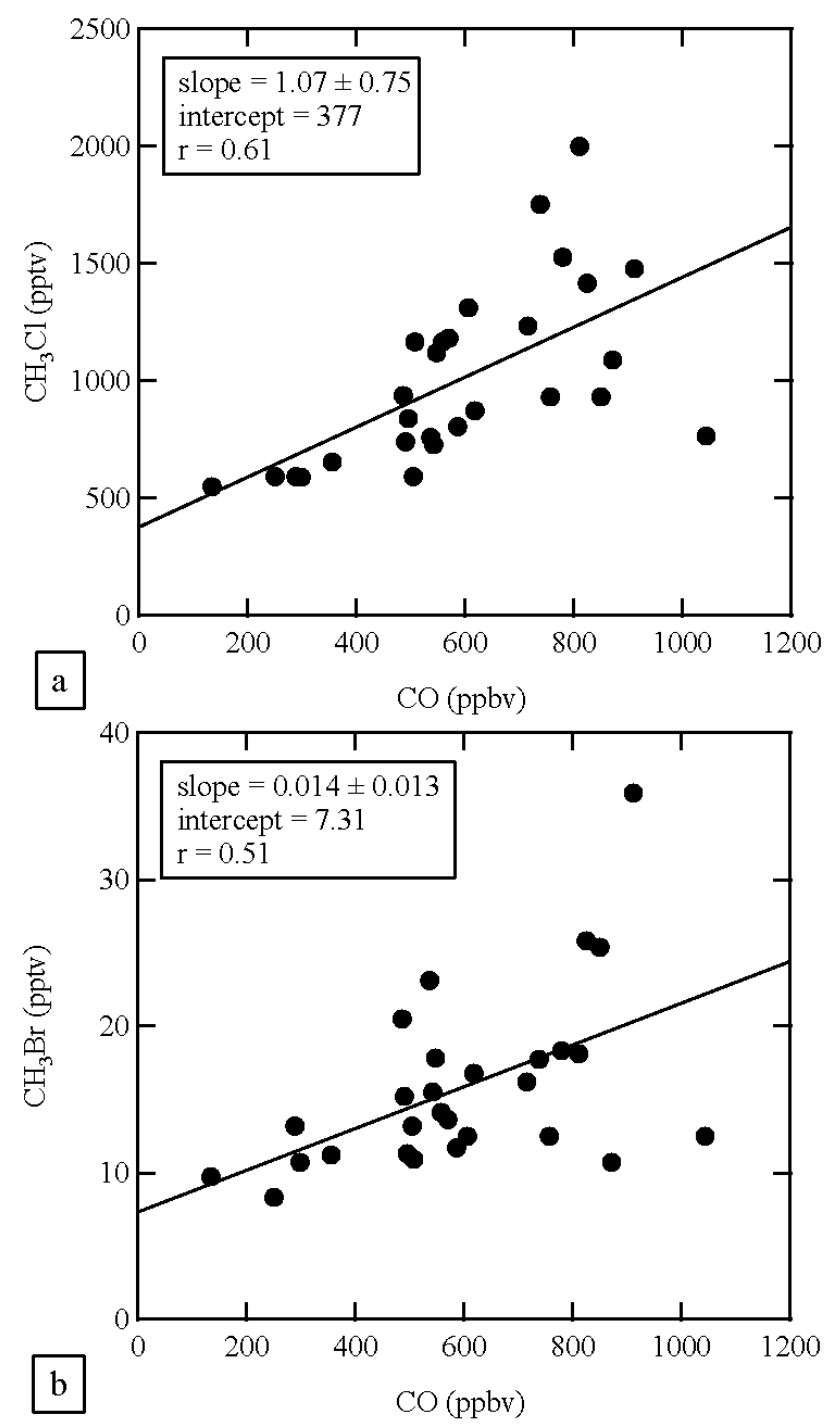

Fig. 8. Correlation plots between methyl halides and $\mathrm{CO}$ observed during June 2006. The line show linear least square fit for (a) $\mathrm{CH}_{3} \mathrm{Cl}$ and (b) $\mathrm{CH}_{3} \mathrm{Br}$ with respect to $\mathrm{CO}$. Annotations are shown for slope and correlation coefficients. Slopes are shown with associated error of $99 \%$ confidence.

agricultural residues; these used mean $\pm \mathrm{SD}$ for $\mathrm{CH}_{3} \mathrm{Cl}$ and only the mean value for $\mathrm{CO}$. Applying a similar calculation for $\Delta \mathrm{CH}_{3} \mathrm{Br} / \Delta \mathrm{CO}$, the values were found to be $0.004-0.02$ for emissions from the burning of savanna and grassland and $0.015-0.035$ for biofuel and agricultural residue burning. Although a comparison with these values suggests that our observations captured reasonably well a mixture of these three types of biomass burning, it is important to note that the correlation coefficients were relatively low due to large scatter of data shifting above and below the linear fit line in the high mixing ratio region.

Further investigation on the impact from biomass burning at the site - fire spot data for the region (AVHRR sensor-type 

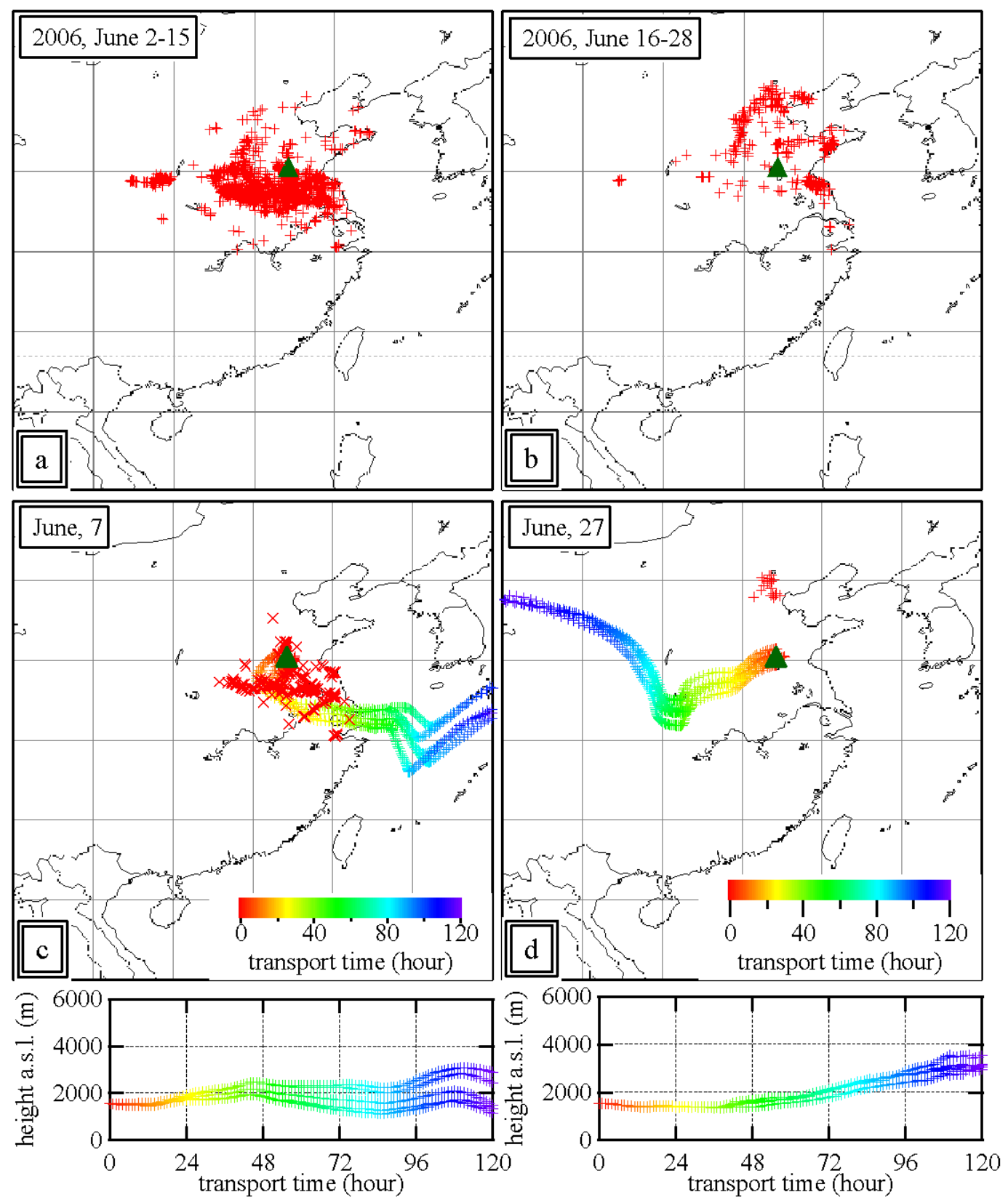

Fig. 9. Fire spot data derived from AVHRR sensor during 2006, (a) 2-15 June and (b) 16-28 June. Location of Mount Tai is indicated by solid triangle. Example of backward trajectory results during the first period and second period are shown in (c) for 7 June and (d) for 27 June, respectively, with color-coded indicated backward time of trajectories. Initial altitude of each backward trajectory was set to $1534 \mathrm{~m}$ a.s.l. (above sea level) corresponding with the site altitude.

dataset) provided by the China Meteorological Administration National Satellite Meteorological Center under the Ministry of Environmental Protection, People's Republic of China - are displayed and categorized into two periods: the first half (2-15 June) is shown in Fig. 9a, and the second half (16-28 June) is shown in Fig. 9b. A highly active fire disturbance near the site was obvious during the first half of the campaign, while the active fire spot noticeably faded out after
16 June. Typical backward trajectory patterns calculated using the HYSPLIT4 model (Draxler and Rolph, 2003) on 7 June - depicted in Fig. 9c with altitude - reveal the route of air masses passing through the burning areas within 1-2 days by color scale (fire spot data were obtained for 6 June) prior to their arrival to the site. On this day, the highest $\mathrm{CH}_{3} \mathrm{Cl}$ mixing ratio was recorded. Trajectories for the latter period of the campaign, depicted in Fig. 9d, suggested a substantial 
weakening influence from biomass burning, as the air masses did not pass over any active fire area. $\mathrm{CH}_{3} \mathrm{Cl}, \mathrm{CH}_{3} \mathrm{Br}$, and $\mathrm{CO}$ data were then categorized into two periods according to trajectory analysis. $\Delta \mathrm{CH}_{3} \mathrm{Cl} / \Delta \mathrm{CO}$ for the first period (Fig. 10a) had a value of 1.88 with an improvement in the correlation coefficient $(r=0.82)$. This value was relatively close to the suggested value for agriculture residue burning. This was also true for the slope between $\mathrm{CH}_{3} \mathrm{Br}$ and $\mathrm{CO}$ - shown in Fig. $10 \mathrm{~b}$ - which revealed a value of $0.012(r=0.72)$; this is close to the values of $0.015-0.035$ suggested for biofuel and agricultural waste burning (Andreae and Merlet, 2001). Although the second period data set revealed a similar slope, this was disregarded due to the relatively insignificant correlation $(r=0.46)$. The difference in characteristics of the first and second period air qualities was also reported by Kanaya et al. (2008) on black carbon, Inomata et al. (2009) for acetaldehyde and acetonitrile, and Yamaji et al. (2009) using the Models-3 Community Multiscale Air Quality Modeling System (CMAQ). Therefore, it is likely that the disturbance from biomass/biofuel burning was more extensive during the first period, and corresponding slopes may be treated as representative values for the regional influence of biomass burning in CEC.

\section{Summary}

VOC measurements were performed at the summit of Mount Tai, located in CEC, during the MTX2006 campaign. VOCs mixing ratios observed at the site revealed fluctuations with similar trends which is a characteristic of air masses with an insignificant local influence but rather regional emission impact. The site is also occasionally influenced by emission of biomass burning suggested by sporadically high mixing ratios of $\mathrm{CH}_{3} \mathrm{Cl}$. This characteristic was also supported by comparison of mixing ratios with those observed at various sites with different characteristics and locations. With the advantage of the site's altitude, which is potentially located above the PBL during the night, observation is possible of regional polluted air during the day and relatively clean air, which can be considered as the regional background level, during the night. A comparison with several free troposphere data sets from airborne observations also supported the useful feature of this site. This is regarded as a significant merit for future long-term observations of atmospheric trace species at Mount Tai. VOC mixing ratio profiles of normalized by ethane data and emission ratios indicated excess acetylene and benzene owing to stationary emission sources, most likely biomass burning. Backward trajectory analysis coupled with fire spot data revealed an extensive impact from biomass burning on air masses arriving to the site during the first period of the campaign (2-15 June); while during the latter period (16-28 June), either the fire spot faded or the trajectory paths did not go over the fire spot. Emission ratios of $\mathrm{CH}_{3} \mathrm{Cl}$ and $\mathrm{CO}$ derived from the two periods are reported

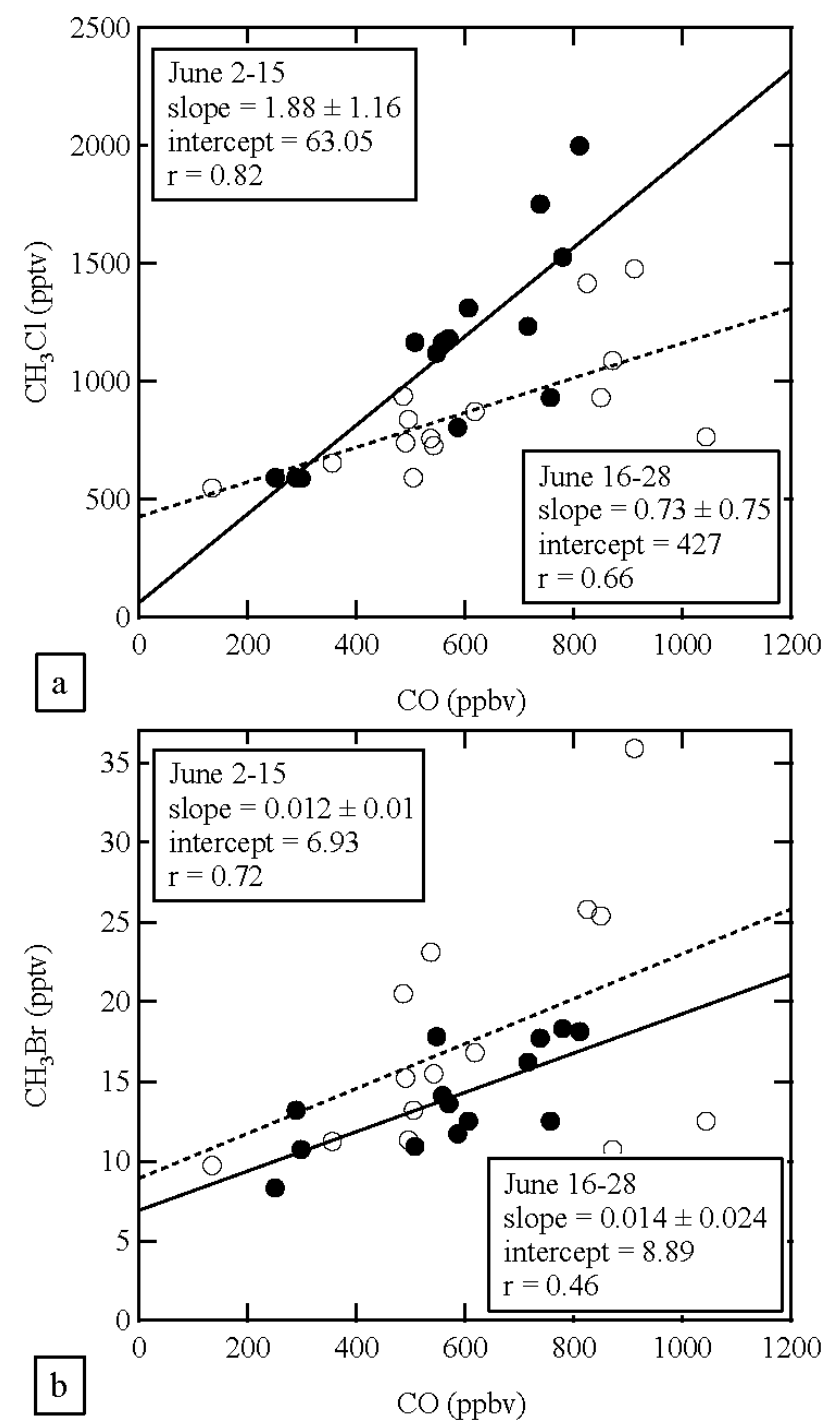

Fig. 10. Correlation plots between $\mathrm{CH}_{3} \mathrm{Cl}$ vs. $\mathrm{CO}$ (a) and $\mathrm{CH}_{3} \mathrm{Br}$ vs. CO (b) of data classified to the first (2-15 June) and the second (16-28 June) periods. Slopes and correlation coefficients derived from linear regression analysis are shown as annotation for each specie and period. Slopes are shown with $99 \%$ confidence interval.

while the slope of $1.88 \pm 1.16$ is suggested as a representative value for air masses perturbed by agricultural waste burning and biofuel burning in this region.

Acknowledgements. This work was supported by Chinese Academy of Science (KZCX2-YW-205), the National Basic Research 973 Grant (2005CB422205), NSFC grant (40775077), MEXT of Japan RR2002 grant, and the Global Environment Research Fund (B-051 and C-081 of the Ministry of the Environment, Japan). Kimitaka Kawamura from the Institute of Low Temperature, Hokkaido University, is acknowledged for the great assistance with the canister sampling throughout the campaign. The authors would like to thank all the members of the MTX2006 campaign for their full support during the campaign, provision 
of supporting data, and useful communications and comments. Anonymous reviewers are also appreciated for their constructive and valuable comments and suggestions.

Edited by: S. C. Liu

\section{References}

Akimoto, H.: Global Air Quality and Pollution, Science, 302(5651), 1716-1719, doi:10.1126/science.1092666, 2003.

Akimoto, H.: Overview of Mount Tai Experiment 2006 (MTX2006), Atmos. Chem. Phys. Discuss., in preparation, 2010.

Andreae, M. O., Atlas, E., Harris, G. W., Helas, G., de Kock, A., Koppmann, R., Maenhaut, W., Man $\phi$, S., Pollock, W. H., Rudolph, J., Scharffe, D., Schebeske, G., and Welling, M.: Methyl halide emissions from savanna fires in southern Africa, J. Geophys. Res., 101(D19), 23603-23613, 1996.

Andreae, M. O. and Merlet, P.: Emissions of trace gases and aerosols from biomass burning, Global Biogeochem. Cy., 15(4), 955-966, 2001.

Atkinson, R.: Atmospheric chemistry of VOCs and $\mathrm{NO}_{\mathrm{x}}$, Atmos. Environ., 34, 2063-2101, 2000.

Barletta, B., Meinardi, S., Rowland, F. S., Chan, C. Y., Wang, X., Zou, S., Chan, L. Y., and Blake, D. R.: Volatile organic compounds in 43 Chinese cities, Atmos. Environ., 32, 5979-5990, 2005.

Barletta, B., Meinardi, S., Simpson, I. J., Rowland, F. S., Chan, C. Y., Wang, X., Zou, S., Chan, L. Y., and Blake, D. R.: Ambient halocarbon mixing ratios in 45 Chinese cities, Atmos. Environ., 40, 7706-7719, 2006.

Barletta, B., Meinardi, S., Simpson, I. J., Atlas, E. L., Beyersdorf, A. J., Baker, A. K., Blake, N. J., Yang, M., Midyett, J. R., Novak, B. J., McKeachie, R. J., Fuelberg, H. E., Sachse, G. W., Avery, M. A., Campos, T., Weinheimer, A. J., Rowland, F. S., and Blake, D. R.: Characterization of volatile organic compounds (VOCs) in Asian and north American pollution plumes during INTEX-B: identification of specific Chinese air mass tracers, Atmos. Chem. Phys., 9, 5371-5388, 2009, http://www.atmos-chem-phys.net/9/5371/2009/.

Bertschi, I. T., Jaffe, D. A., Jaeglé, L., Price, H. U., and Dennison, J. B.: PHOBEA/ITCT 2002 airborne observations of transpacific transport of ozone, $\mathrm{CO}$, volatile organic compounds, and aerosols to the northeast Pacific: Impacts of Asian anthropogenic and Siberian boreal fire emissions, J. Geophys. Res., 109, D23S12, doi:10.1029/2003JD004328, 2004.

Blake, D. R. and Rowland, F. S.: Urban Leakage of liquefied petroleum gas and its impact on Mexico City air quality, Science, 269, 953-956, 1995.

Blake, D. R., Chen, T. Y., Smith Jr., T. W., Wang, C. J.-L., Wingenter, O. W., Blake, N. J., Rowland, F. S., and Mayer, E. W.: Three-dimensional distribution of nonmenthane hydrocarbons and halocarbons over the northwestern Pacific during the 1991 Pacific Exploratory Mission (PEM-West A), J. Geophys. Res., 101(D1), 1763-1778, 1996.

Blake, N. J., Blake, D. R., Sive, B. C., Chen, T. Y., Rowland, F. S., Collins Jr., J. E., Sachse, G. W., and Anderson, B. E.: Biomass burning emissions and vertical distribution of atmospheric methyl halides and other reduced carbon gases in the
South Atlantic region, J. Geophys. Res., 101(D19), 2415124164, 1996.

Blake, N. J, Blake, D. R., Chen, T. Y., Collins Jr., J. E., Sachse, G. W., Anderson, B. E., and Rowland, F. S.: Distribution and seasonality of selected hydrocarbons and halocarbons over the western Pacific basin during PEM-West A and PEM-West B, J. Geophys. Res., 102(D23), 28315-28331, 1997.

Blake, N. J., Blake, D. R., Simpson, I. J., Lopez, J. P., Johnston, N. A. C., Swanson, A. L., Katzenstein, A. S., Meinardi, S., Sive, B. C., Colman, J. J., Atlas, E., Flocke, F., Vay, S. A., Avery, M. A., and Rowland, F. S.: Large-scale latitudinal and vertical distribution of NMHCs and selected halocarbons in the troposphere over the Pacific Ocean during March-April 1999 Pacific Exploratory Mission (PEM-Tropics B), J. Geophys. Res., 106(D23), 3262732644, 2001.

Blake, N. J., Blake, D. R., Simpson, I. J., Meinardi, S., Swanson, A. L., Lopez, J. P., Katzenstein, A. S., Barletta, B., Shirai, T., Atlas, E., Sachse, G., Avery, M., Vay, S., Fuelberg, H., Kiley, C. M., Kita, K., and Rowland, F. S.: NMHCs and Halocarbons in Asian continental outflow during the Transport and Chemical Evolution over the Pacific (TRACE-P) Field Campaign: Comparison With PEM-West B, J. Geophys. Res., 108(D20), 8806, doi:10.1029/2002JD003367, 2003.

Carmichael, G. R., Tang, Y., Kurata, G., Uno, I., Streets, D., Woo, J.-H., Huang, H., Yienger, J., Lefer, B., Shetter, R., Blake, D., Atlas, E., Fied, A., Apel, E., Eisele, F., Cantrell, C., Avery, M., Barrick, J., Sachse, G., Brune, W., Sandholm, S., Kondo, Y., Singh, H., Talbot, R., Bandy, A., Thorton, D., Clarke, A., and Heikes, B.: Regional-scale chemical transport modeling in support of the analysis of observations obtained during the TRACE-P experiment, J. Geophys. Res., 108(D21), 8823, doi:10.1029/2002JD003117, 2003.

Central Intelligence Agency (CIA): The World Factbook: https://www.cia.gov/library/publications/the-world-factbook/ geos/ch.html, last access: 17 December 2008.

Chan, C. Y., Chan, L. Y., Wang, X. M., Liu, Y. M., Lee, S. C., Zou, S. C., Sheng, G. Y., and Fu, J. M.: Volatile organic compounds in roadside microenvironments of metropolitan Hong Kong, Atmos. Environ., 36, 2039-2047, 2002.

Chan, C. Y., Tang, J. H., Li, Y. S., and Chan, L. Y.: Mixing ratios and sources of halocarbons in urban, semi-urban and rural sites of the Pearl River Delta, South China, Atmos. Environ., 40, 7331-7345, 2006.

Chan, L. Y., Chu, K. W., Zou, S. C., Chan, C. Y., Wang, X. M., Barletta, B., Blake, D. R., Guo, H., and Tsai, W. Y.: Characteristics of nonmethane hydrocarbons (NMHCs) in industrial, industrialurban, and industrial-suburban atmospheres of the Pearl River Delta (PRD) region of south China, J. Geophys. Res., 111, D11304, doi:10.1029/2005JD006481, 2006.

Chan, L. Y. and Chu, K. W.: Halocarbons in the atmosphere of the industrial-related Pearl River Delta region of China, J. Geophys. Res., 112, D04305, doi:10.1029/2006JD007097, 2007.

de Gouw, J. A., Cooper, O. R., Warneke, C., Hudson, P. K., Fehsenfeld, F. C., Holloway, J. S., Hübler, G., Nicks Jr., D. K., Nowak, J. B., Parrish, D. D., Ryerson, T. B., Atlas, E. L., Donnelly, S. G., Schauffler, S. M., Stroud, V., Johnson, K., Carmichael, G. R., and Streets, D. G.: Chemical composition of air masses transported from Asia to the US West Coast during ITCT 2K2: Fossil fuel combustion versus biomass-burning signatures, J. Geophys. 
Res., 109, D23S20, doi:10.1029/2003JD004202, 2004.

Draxler, R. R. and Rolph, G. D.: HYSPLIT (HYbrid SingleParticle Lagrangian Integrated Trajectory) Model access via NOAA ARL READY Website http://www.arl.noaa.gov/ready/ hysplit4.html, last access: 17 April 2007, NOAA Air Resources Laboratory, Silver Spring, MD, 2003.

Elliott, S., Blake, D. R., Blake, N. J., Dubey, M. K., Rowland, F. S., Sive, B. C., and Smith, F. A.: BIBLE A whole-air sampling as a window on Asian biogeochemistry, J. Geophys. Res., 108(D3), 8407, doi:10.1029/2001JD000790, 2003.

Fernandes, S. D., Trautmann, N. M., Streets, D. G., Roden, C. A., and Bond, T. C.: Global biofuel use, 1850-2000, Global Biogeochem. Cy., 21, GB2019, doi:10.1029/2006GB002836, 2007.

Guo, H., Wang, T., Simpson, I. J., Blake, D. R., Yu, X. M., Kwok, Y. H., and Li, Y. S.: Source contributions to ambient VOCs and CO at a rural site in eastern China, Atmos. Environ., 38, 4551-4560, 2004.

Guo, H. T., Wang, T., Blake, D. R., Simpson, I. J., Kwok, Y. H., and Li, Y. S.: Regional and local contributions to ambient nonmethane volatile organic compounds at a polluted rural/coastal site in Pearl River Delta, China, Atmos. Environ., 40, 2345 2359, 2006.

Guo, H., So, K. L., Simpson, I. J., Barletta, B., Meinardi, S., and Blake, D. R.: $\mathrm{C}_{1}-\mathrm{C}_{8}$ volatile organic compounds in the atmosphere of Hong Kong: Overview of atmospheric processing and source apportionment, Atmos. Environ., 41, 1456-1472, 2007.

Guttikunda, S. K., Tang, Y., Carmichael, G. R., Kurata, G., Pan, L., Streets, D. G., Woo, J. H., Thongboonchoo, N., and Fried, A.: Impacts of Asian megacity emissions on regional air quality during spring 2001, J. Geophys. Res., 110, D20301, doi:10.1029/2004JD004921, 2005.

Ho, K. F., Lee, S. C., and Chiu, G. M. Y.: Characterization of selected volatile organic compounds, polycyclic aromatic hydrocarbons and carbonyl compounds at a roadside monitoring station, Atmos. Environ., 36, 57-65, 2002.

Hoell, J. M., Davis, D. D., Liu, S. C., Newell, R., Shipham, M., Akimoto, H., McNeal, R. J., Bendura, R. J., and Drewry, J. W.: Pacific Exploratory Mission-West A (PEM-West A): SeptemberOctober 1991, J. Geophys. Res., 101, 1641-1653, 1996.

Hoell, J. M., Davis, D. D., Liu, S. C., Newell, R., Akimoto, H., McNeal, R. J., and Bendura, R. J.: Pacific Exploratory MissionWest B: February-March, 1994, J. Geophys. Res., 102, 2823328239, 1997.

Hoell, J. M., Davis, D. D., Jacob, D. J., Rodgers, M. O., Newell, R. E., Fuelberg, H. E., McNeal, R. J., Raper, J. L., and Bendura, R. J.: Pacific Exploratory Mission in the Tropical Pacific: PEM Tropics A, August-September 1996, J. Geophys. Res., 104, 5567-5583, 1999.

Inomata, S., Tanimoto, H., Kato, S., Suthawaree, J., Kanaya, Y., Pochanart, P., Liu, Y., and Wang, Z.: PTR-MS measurements of non-methane volatile organic compounds during an intensive field campaign at the summit of Mount Tai, China, in June 2006, Atmos. Chem. Phys. Discuss., 9, 26697-26734, 2009, http://www.atmos-chem-phys-discuss.net/9/26697/2009/.

Jacob, D., Crawford, J. H., Kleb, M. M., Connors, V. S., Bendura, R. J., Raper, J. L., Sachse, G. W., Gille, J. C., Emmons, L., and Heald, C. L.: Transport and Chemical Evolution over the Pacific (TRACE-P) aircraft mission: Design, execution, and first results, J. Geophys. Res., 108(D20), 9000, doi:10.1029/2002JD003276,
2003.

Jain, A. K., Tao, Z., Yang, X., and Gillespie, C.: Estimates of global biomass burning emissions for reactive greenhouse gases $(\mathrm{CO}$, NMHCs, and $\mathrm{NO}_{\mathrm{x}}$ ) and $\mathrm{CO}_{2}$, J. Geophys. Res., 111, D06304, doi:10.1029/2005JD006237, 2006.

Jobson, B. T., Niki, H., Yokouchi, Y., Bottenheim, J., Hopper, F., and Leaitch, R.: Measurements of $\mathrm{C}_{2}-\mathrm{C}_{6}$ hydrocarbons during the Polar Sunrise 1992 Experiment: Evidence for $\mathrm{Cl}$ atom and $\mathrm{Br}$ atom chemistry, J. Geophys. Res., 99(D12), 25355-25368, 1994.

Jost, C., Trentmann, J., Sprung, D., Andreae, M. O., McQuaid, J. B., and Barjat, H.: Trace gas chemistry in a young biomass burning plume over Namibia: Observations and model simulations, J. Geophys. Res., 108(D13), 8482, doi:10.1029/2002JD002431, 2003.

Kanaya, Y., Komazaki, Y., Pochanart, P., Liu, Y., Akimoto, H., Gao, J., Wang, T., and Wang, Z.: Mass concentrations of black carbon measured by four instruments in the middle of Central East China in June 2006, Atmos. Chem. Phys., 8, 7637-7649, 2008, http://www.atmos-chem-phys.net/8/7637/2008/.

Kanaya, Y., Pochanart, P., Liu, Y., Li, J., Tanimoto, H., Kato, S., Suthawaree, J., Inomata, S., Taketani, F., Okuzawa, K., Kawamura, K., Akimoto, H., and Wang, Z. F.: Rates and regimes of photochemical ozone production over Central East China in June 2006: a box model analysis using comprehensive measurements of ozone precursors, Atmos. Chem. Phys., 9, 7711-7723, 2009 ,

http://www.atmos-chem-phys.net/9/7711/2009/.

Kato, N. and Akimoto, H.: Anthropogenic emissions of $\mathrm{SO}_{2}$ and $\mathrm{NO}_{\mathrm{x}}$ in Asia: emission inventories, Atmos. Environ., 26A, 2997 3017, 1992.

Kato, S., Kajii, Y., Itokazu, R., Hirokawa, J., Koda, S., and Kinjo, Y.: Transport of atmospheric carbon monoxide, ozone, and hydrocarbons from Chinese coast to Okinawa island in the Western Pacific during winter, Atmos. Environ., 38, 2975-2981, 2004.

Kato, S., Ui, T., Uematsu, M., and Kajii, Y.: Trace Gas Measurements over Northwest Pacific during IOC Cruises 2002, Geochem. Geophy. Geosy., 8, Q06M10, doi:10.1029/2006GC001241, 2007.

Klimont, Z., Streets, D. G., Gupta, S., Cofala, J., Lixin, F., and Ichikawa, Y.: Anthropogenic emissions of non-methane volatile organic compounds in China, Atmos. Environ., 36, 1309-1322, 2002.

Kondo, Y., Morino, Y., Takegawa, N., Koike, M., Kita, K., Miyazaki, Y., Sachse, G. W., Vay, S. A., Avery, M. A., Flocke, F., Weinheimer, A. J., Eisele, F. L., Zondlo, M. A., Weber, R. J., Singh, H. B., Chen, G., Crawford, J., Blake, D. R., Fuelberg, H. E., Clarke, A. D., Talbot, R. W., Sandholm, S. T., Browell, E. V., Streets, D. G., and Liley, B.: Impacts of biomass burning in Southeast Asia on ozone and reactive nitrogen over the western Pacific in spring, J. Geophys. Res., 109, D15S12, doi:10.1029/2003JD004203, 2004.

Lee, B. S. and Wang, J. L.: Mixing ratio variation of isoprene and its implications for peak ozone mixing ratio, Atmos. Environ., 40, 5486-5495, 2006.

Liu, C., Xu, Z., Du, Y., and Guo, H.: Analyses of Volatile organic compounds mixing ratios and variation trends in the air of Changchun, the northeast of China, Atmos. Environ., 34, 44594466, 2000. 
Liu, Y., Shao, M., Lu, S., Chang, C.-C., Wang, J.-L., and Chen, G.: Volatile Organic Compound (VOC) measurements in the Pearl River Delta (PRD) region, China, Atmos. Chem. Phys., 8, 1531$1545,2008 \mathrm{a}$, http://www.atmos-chem-phys.net/8/1531/2008/.

Liu, Y., Shao, M., Fu, L., Lu, S., Zeng, L., and Tang, D.: Source profiles of volatile organic compounds (VOCs) measured in China: Part I, Atmos. Environ., 42(25), 6247-6260, 2008 b.

Liu, Y., Shao, M., Lu, S., Chang, C. C., Wang, J. L., and Fu, L.: Source apportionment of ambient volatile organic compounds in the Pearl River Delta, China: Part II, Atmos. Environ., 42(25), 6261-6274, 2008c.

Lü, A., Tian, H., Liu, M., Liu, J., and Melillo, J. M.: Spatial and temporal patterns of carbon emissions from forest fires in China from 1950 to 2000, J. Geophys. Res., 111, D05313, doi:10.1029/2005JD006198, 2006.

Luo, C., St. John, J. C., Xiuji, Z., Lam, K. S., Wang, T., and Chameides, W. L.: A nonurban ozone air pollution episode over eastern China: Observations and model simulations, J. Geophys. Res., 105(D2), 1889-1908, 2000.

Ma, J., Zheng, X., and Xu, X.: Comment on "Why does surface ozone peak in summertime at Waliguan?" by Bin Zhu et al., Geophys. Res. Lett., 32, L01805, doi:10.1029/2004GL021683, 2005.

McCulloch, A., Aucott, M. L., Graedel, T. E., Kleiman, G., Midgley, P. M., and Li, Y. F.: Industrial emissions of trichloroethene, tetrachloroethene, and dichloromethane: Reactive Chlorine Emissions Inventory, J. Geophys. Res., 104(D7), 8417-8427, 1999.

Parrish, D. D., Kondo, Y., Cooper, O. R., Brock, C. A., Jaffe, D. A., Trainer, M., Ogawa, T., Hübler, G., and Fehsenfeld, F. C.: Intercontinental Transport and Chemical Transformation 2002 (ITCT 2K2) and Pacific Exploration of Asian Continental Emission (PEACE) experiments: An overview if the 2002 winter and spring intensives, J. Geophys. Res., 105, D23S01, doi10:1029/2004JD004980, 2004.

Pochanart, P., Kanaya, Y., Li, J., Komazaki, Y., Akimoto, H., Liu, Y., Wang, X., and Wang, Z.: Surface ozone, carbon monoxide and black carbon over Central East China during MTX2006, Atmos. Chem. Phys. Dis., in preparation, 2010.

Qin, D.: CFC-12 and CFC-113 in an urban area of Beijing, China, Atmos. Environ., 41(38), 8424-8430, 2007.

Sharma, U. K, Kajii, Y., and Akimoto, H.: Measurement of NMHCs at Oki Island, Japan: an evidence of long range transport, Geophys. Res. Lett., 27(16), 2505-2508, 2000.

Shao, M., Lu, S., Liu, Y., Xie, X., Chang, C., Huang, S., and Chen, Z.: Volatile organic compounds measured in summer in Beijing and their role in ground level ozone formation, J. Geophys. Res., 114, D00G06, doi:10.1029/2008JD010863, 2009.

Shirai, T., Blake, D. R., Meinardi, S., Rowland, F. S., RussellSmith, J., Edwards, A., Kondo, Y., Koike, M., Kita, K., Machida, T., Takegawa, N., Nishi, N., Kawakami, S., Ogawa, T.: Emission estimates of selected volatile organic compounds from tropical savanna burning in northern Australia, J. Geophys. Res., 108(D3), 8406, doi:10.1029/2001JD000841, 2003.

Simpson, I. J., Blake, N. J., Blake, D. R., Meinardi, S., Andersen, M. P. S., and Rowland, F. S.: Strong evidence for negligible methyl chloroform $\left(\mathrm{CH}_{3} \mathrm{CCl}_{3}\right)$ emissions from biomass burning, Geophys. Res. Lett., 34, L10805, doi:10.1029/2007GL029383,
2007.

So, K. L. and Wang, T.: $\mathrm{C}_{3}-\mathrm{C}_{13}$ non-methane hydrocarbons in subtropical Hong Kong: spatial-temporal variations, source-receptor relationships and photochemical reactivity, Sci. Total Environ., 328, 161-174, 2004.

Streets, D. G. and Waldhoff, S. T.: Biofuel use in Asia and acidifying emissions, Energy, 23(12), 1029-1042, 1998.

Streets, D. G. and Waldhoff, S. T.: Greenhouse-gas emissions from biofuel combustion in Asia, Energy, 24, 841-855, 1999.

Streets, D. G. and Waldhoff, S. T.: Present and future emissions of air pollutants in China: $\mathrm{SO}_{2}, \mathrm{NO}_{\mathrm{x}}$, and $\mathrm{CO}$, Atmos. Environ., 34, 363-374, 2000.

Streets, D. G., Gupta, S., Waldhoff, S. T., Wang, M. Q., Bond, T. M., and Yiyun, B.: Black carbon emissions in China, Atmos. Environ., 35, 4281-4296, 2001.

Streets, D. G., Bond, T. C., Carmichael, G. R., Fernandes, S. D., Fu, Q., He, D., Klimont, Z., Nelson, S. M., Tsai, N. Y., Wang, M. Q., Woo, J. H., and Yarber, K. F.: An inventory of gaseous and primary aerosol emissions in Asia in the year 2000, J. Geophys. Res., 108(D21), 8809, doi:10.1029/2002JD003093, 2003a.

Streets, D. G., Yarber, K. F., Woo, J. H., and Carmichael, G. R.: Biomass burning in Asia: Annual and seasonal estimates and atmospheric emissions, Global Biogeochem. Cy., 17(4), 1099, doi:10.1029/2003GB002040, 2003b.

Suthawaree, J., Kato, S., Takami, A., Kadena, H., Toguchi, M., Yogi, K., Hatakeyama, S., and Kajii, Y.: Observation of ozone and carbon monoxide at Cape Hedo, Japan: Seasonal variation and influence of long-range transport, Atmos. Environ., 42, 2971-2981, 2008.

Swanson, A. L., Blake, N. J., Atlas, E., Flocke, F., Blake, D. R., and Rowland, F. S.: Seasonal variations of $\mathrm{C}_{2}-\mathrm{C}_{4}$ nonmethane hydrocarbons and $\mathrm{C}_{1}-\mathrm{C}_{4}$ alkyl nitrates at the Summit research station in Greenland, J. Geophys. Res., 108(D2), 4065, doi:10.1029/2001JD001445, 2003.

Takigawa, M., Sudo, K., Akimoto, H., Kita, K., Takegawa, N., Kondo, Y., and Takahashi, M.: Estimation of the contribution of intercontinental transport during the PEACE campaign by using a global model, J. Geophys. Res., 110, D21313, doi:10.1029/2005JD006226, 2005.

Tang, J. H., Chan, L. Y., Chan, C. Y., Li, Y. S., Chang, C. C., Liu, S. C., $\mathrm{Wu}, \mathrm{D}$. , and Li, Y. D.: Characteristics and diurnal variations of NMHCs at urban, suburban, and rural sites in the Pearl River Delta and a remote site in South China, Atmos. Environ., 41, 8620-8632, 2007.

Thomas, V. M., Bedford, J. A., and Cicerone, R. J.: Bromine emissions from leaded gasoline, Geophys. Res. Lett., 24(11), 13711374, 1997.

Talbot, R. W., Dibb, J. E., Lefer, B. L., Bradshaw, J. D., Sandholm, S. T., Blake, D. R., Blake, N. J., Sachse, G. W., Collins Jr., J. E., Heikes, B. G., Merrill, J. T., Gregory, G. L., Anderson, B. E., Singh, H. B., Thornton, D. C., Bandy, A. R., and Pueschel, R. F.: Chemical characteristics of continental outflow from Asia to the troposphere over the western Pacific Ocean during February-March 1994: Results from PEM-West B, J. Geophys. Res., 102(D23), 28255-28274, 1997.

Tsai, W. Y., Chan, L. Y., Blake, D. R., and Chu, K. W.: Vehicular fuel composition and atmospheric emissions in South China: Hong Kong, Macau, Guangzhou, and Zhuhai, Atmos. Chem. Phys., 6, 3281-3288, 2006, 
http://www.atmos-chem-phys.net/6/3281/2006/.

Velasco, E., Lamb, B., Westberg, H., Allwine, E., Sosa, G., ArriagaColina, J. L., Jobson, B. T., Alexander, M. L., Prazeller, P., Knighton, W. B., Rogers, T. M., Grutter, M., Herndon, S. C., Kolb, C. E., Zavala, M., de Foy, B., Volkamer, R., Molina, L. T., and Molina, M. J.: Distribution, magnitudes, reactivities, ratios and diurnal patterns of volatile organic compounds in the Valley of Mexico during the MCMA 2002 \& 2003 field campaigns, Atmos. Chem. Phys., 7, 329-353, 2007,

http://www.atmos-chem-phys.net/7/329/2007/.

Wang, T., Cheung, T. F., Li, Y. S., Yu, X. M., and Blake, D. R.: Emission characteristics of $\mathrm{CO}, \mathrm{NO}_{\mathrm{x}}, \mathrm{SO}_{2}$ and indications of biomass burning observed at a rural site in eastern China, J. Geophys. Res., 107(D12), 4157, doi:10.1029/2001JD000724, 2002.

Wang, T., Ding, A. J., Blake, D. R., Zahorowski, W., Poon, C. N., and Li, Y. S.: Chemical characterization of the boundary layer outflow of air pollution to Hong Kong during February-April 2001, J. Geophys. Res., 108(D20), 8787, doi:10.1029/2002JD003272, 2003.

Wang, T., Wong, C. H., Cheung, T. F., Blake, D. R., Arimoto, R., Baumann, K., Tang, J., Ding, G. A., Yu, X. M., Li, Y. S., Streets, D. G., and Simpson, I. J.: Relationships of trace gases and aerosols and the emission characteristics at Lin'an, a rural site in eastern China, during spring 2001, J. Geophys. Res., 109, D19S05, 4157, doi:10.1029/2003JD004119, 2004.

Wang, X. P., Mauzerall, D. L., Hu, Y. T., Russell, A. G., Larson, E. D., Woo, J. H., Streets, D. G., and Guenther, A.: A highresolution emission inventory for eastern China in 2000 and three scenarios for 2020, Atmos. Environ., 39, 5917-5933, 2005.
Wong, H. L. A., Wang, T., Ding, A., Blake, D. R., and Nam, J. C.: Impact of Asian continental outflow on the mixing ratios of $\mathrm{O}_{3}, \mathrm{CO}, \mathrm{NMHCs}$ and halocarbons on Jeju Island, South Korea during March 2005, Atmos. Environ., 41, 2933-2944, 2007.

Woo, J. H., Streets, D. G., Carmichael, G. R., Tang, Y., Yoo, B., Lee, W. C., Thongboonchoo, N., Pinnock, S., Kurata, G., Uno, I., Fu, Q., Vay, S., Sachse, G. W., Blake, D. R., Fried, A., and Thornton, D. C.: Contribution of biomass and biofuel emissions to trace gas distributions in Asia during the TRACE-P experiment, J. Geophys. Res., 108(D21), 8812, doi:10.1029/2002JD003200, 2003.

World Data Centre for Greenhouse Gases (WDCGG): http://gaw. kishou.go.jp/wdcgg/, last access: 27 June 2008.

Xie, X., Shao, M., Liu, Y., Lu, S., Chang, C., and Chen, Z.: Estimate of initial isoprene contribution to ozone formation potential in Beijing, China, Atmos. Environ., 42, 6000-6010, 2008.

Yamaji, K., Li, J., Uno, I., Kanaya, Y., Komazaki, Y., Pochanart, P., Liu, Y., Takigawa, M., Ohara, T., Yan, X., Wang, Z., and Akimoto, H.: Impact of open crop residual burning on air quality over Central Eastern China during the Mount Tai Experiment 2006 (MTX2006), Atmos. Chem. Phys. Discuss., 9, 22103-22141, 2009, http://www.atmos-chem-phys-discuss.net/9/22103/2009/.

Zhu, B. H., Akimoto, H., Wang, Z., Sudo, K., Tang, J., and Uno, I.: Why does surface ozone peak in summertime at Waliguan?, Geophys. Res. Lett., 31, L17104, doi:10.1029/2004GL020609, 2004. 